\title{
Effects of precalving body condition score and prepartum feeding level on production, reproduction, and health parameters in pasture-based transition dairy cows
}

\author{
J. R. Roche, ${ }^{\star 1}$ S. Meier, ${ }^{*}$ A. Heiser,† M. D. Mitchell, $\ddagger$ C. G. Walker,§ M. A. Crookenden,§ M. Vailati Riboni,\# \\ J. J. Loor,\# and J. K. Kay* \\ *DairyNZ Limited, Private Bag 3221, Hamilton, New Zealand 3240 \\ †AgResearch, Hopkirk Research Institute, Grasslands Research Centre, Palmerston North, New Zealand 4442 \\ ¥University of Queensland, Centre for Clinical Research, Royal Brisbane \& Women’s Hospital Campus, Herston, Queensland, Australia 4029 \\ §DairyNZ Limited, c/o University of Auckland, 3A Symonds St., Auckland, New Zealand 1010 \\ \#Department of Animal Sciences, University of Illinois, Urbana 61801
}

\begin{abstract}
Precalving feeding level alters postcalving energy balance, dry matter intake, the liver and adipose tissue transcriptome, hepatic lipidosis, and the risk of metabolic diseases in both high-production cows consuming total mixed rations and moderate-production cows grazing pasture. We hypothesized that the reported benefits of a controlled restriction before calving are dependent on precalving body condition score (BCS): low BCS animals would not benefit from reduced feeding levels precalving, but high BCS cows would have metabolic and immunomodulatory profiles indicative of an improved health status. One hundred sixty-one days before calving, 150 cows were allocated randomly to 1 of 6 treatment groups $(\mathrm{n}=25)$ in a $2 \times 3$ factorial arrangement: 2 precalving BCS categories (4.0 and 5.0; based on a 10-point scale: BCS4 and BCS5, respectively) and 3 levels of energy intake during the 3 wk preceding calving $(75,100$, and $125 \%$ of estimated requirements). Cows in the BCS4 and BCS5 groups were managed through late lactation to ensure that target calving BCS was achieved at dry off. Cows were then fed to maintain this BCS target until 3 wk before expected calving date, at which point they were managed within their allotted precalving energy intake treatments by offering different allowances of fresh pasture/cow per day. Milk production, body weight, and BCS were measured weekly; blood was sampled weekly before and after calving and on d $0,1,2,3$, and 4 relative to calving. Aspirated plasma was assayed for nonesterified fatty acids, $\beta$-hydroxybutyrate, total protein, albumin, cholesterol, haptoglobin, IL-1 $\beta$, IL-6,
\end{abstract}

Received December 21, 2014.

Accepted June 2, 2015.

${ }^{1}$ Corresponding author: john.roche@dairynz.co.nz total antioxidant capacity, and reactive oxygen species. Liver was sampled wk 1, 2, and 4 postcalving for triacylglycerol analysis. Results confirm that precalving BCS and precalving feeding level have both independent and interdependent effects on production and health characteristics of transition dairy cows. Irrespective of precalving BCS, a controlled restriction precalving reduced the net release of nonesterified fatty acids from adipose tissue postpartum and increased plasma calcium concentrations, reducing the risk of milk fever. Fatter cows produced more milk but lost more BCS postcalving and had greater blood $\beta$-hydroxybutyrate concentrations and increased hepatic lipidosis. In comparison, after calving, indicators of reduced immune competence were accentuated in BCS4 cows subjected to a feed restriction before calving, probably increasing the risk of infectious diseases. It would appear from these results that optimally conditioned cows will benefit from a short-term (2-3 wk) controlled feed restriction (75-90\% of requirements), whereas cows in less than optimal condition should be fed to requirements before calving.

Key words: transition cow, health, welfare, hypocalcemia

\section{INTRODUCTION}

The period of transition between late pregnancy and early lactation poses a significant metabolic challenge to the high-yielding dairy cow (Bell, 1995; Drackley, 1999). Roche (2012) estimated that the cost of failing to transition optimally between pregnancy and lactation cost the New Zealand dairy industry in excess of $\$ 1.0$ billion per annum. Immune competence is compromised during this period (Burton et al., 2001), even in low- to moderate-yielding grazing dairy cows (Crookenden et al., 2014; Heiser et al., 2015); this is likely a major reason for cows failing to transition and 
may be responsible for the estimated 30 to $50 \%$ of dairy cows that experience health disorders in the period immediately postcalving (LeBlanc, 2010).

For almost a century, it has been accepted that dairy cows in the weeks preceding calving should be fed ad libitum amounts of high quality feeds. Boutflour (1928) identified "neglect of the preparation of the cow for her next lactation period" as 1 of the 4 factors most limiting milk production. In his article, he recommended "steaming up" the cow during the weeks precalving. Furthermore, epidemiological studies (Dyk et al., 1995; Sheehy et al., 2014) indicated positive associations between prepartum NEFA concentration or BCS loss and the incidence of postpartum metabolic and infectious diseases. Similarly, Bertics et al. (1992) concluded that providing cows with additional feed in the weeks before calving reduced liver triacylglycerol (TAG) concentration on the day of calving. Based on these results, it was concluded that BCS loss and NEFA release prepartum should be avoided.

Subsequent experiments designed to generate a controlled release of NEFA prepartum, however, did not identify the metabolic disturbances reported in the epidemiological studies (Agenäs et al., 2003; Holtenius et al., 2003; Roche et al., 2005; Douglas et al., 2006; Loor et al., 2006). In fact, energy balance (EBAL) and metabolic and molecular indicators of health were improved in the cows with higher NEFA prepartum in many studies (Roche et al., 2005; Douglas et al., 2006; Loor et al., 2006; Roche, 2007). These results, along with animal behavior data noting less time spent feeding and lower DMI before calving in animals that presented with infectious (Huzzey et al., 2007) and metabolic (Goldhawk et al., 2009) diseases after calving indicate that, although an increase in blood NEFA before calving was associated with postpartum disease, it was not causative. Subsequent studies (Janovick and Drackley, 2010; Janovick et al., 2011) have since confirmed that feeding a low-energy diet or restricting the volume of feed a cow consumes in the weeks before calving improves indicators of metabolic health.

Although there are an increasing number of studies aimed at understanding metabolic and molecular changes associated with dietary energy intake before calving (Schmitt et al., 2011; Akbar et al., 2013; Graugnard et al., 2013; Ji et al., 2014), the contributory factors remain poorly understood. One animal factor that could interact with precalving level of feeding is cow BCS. Fatter cows mobilize more BCS in early lactation and have reduced DMI and greater liver TAG (Bobe et al., 2004; Roche et al., 2009; Akbar et al., 2015). Consistent with the hypothesis that the effect of precalving level of feeding is dependent on precalving BCS, Roche et al. (2013) reported significant effects of calving BCS on cow metabolic profiles. Therefore, it is plausible that the reported effects of feeding less energy precalving are dependent on the BCS of the cow precalving, with fatter cows more likely to benefit from controlled NEFA release prepartum. The objective of the presented experiment was to determine the relationship between precalving BCS and level of feeding on production and reproduction variables and on indicators of metabolic health.

\section{MATERIALS AND METHODS}

The Ruakura Animal Ethics Committee (Hamilton, New Zealand) approved all animal manipulations in accordance with the New Zealand Animal Welfare Act (1999). The experiment was undertaken at Scott Farm, Hamilton, New Zealand. $\left(37^{\circ} 46^{\prime} \mathrm{S} 175^{\circ} 18^{\prime} \mathrm{E}\right)$ between January and October 2013.

A group of 170 mid-lactation dairy cows of mixed age and breed (Holstein-Friesian, Jersey, Holstein-Friesian $\times$ Jersey) were considered as candidates for the experiment. From these, 150 cows that passed a veterinary clinical examination, which included a full pathology health panel, were enrolled in the experiment on January 21, 2013. Cows were allocated randomly to 1 of 6 treatment groups (25 cows per group) in a $2 \times 3$ factorial arrangement: 2 precalving BCS categories (4.0 and 5.0; based on a 10-point scale, where 1 is emaciated and 10 obese; Roche et al., 2004: BCS4 and BCS5, respectively) and 3 levels of energy intake during the 3 wk preceding calving $(75,100$, and $125 \%$ of estimated requirements; Roche et al., 2005: Feed75, Feed100, and Feed125, respectively). Although cow allocation to treatment was random, groups were assessed to ensure they were balanced for age, breed, BCS at the time of enrolment, and expected calving date. Age at enrollment was $4.0 \pm 1.4 \mathrm{yr}($ mean $\pm \mathrm{SD})$. Mean calving date was July $11 \pm 10.2 \mathrm{~d}$.

\section{Approach to Establish Treatment Groups}

From February 1 (205 DIM), feeding levels were manipulated with the intention of generating the 2 BCS treatment groups $(\mathrm{n}=75)$ before the end of lactation. Three groups of cows were managed separately to achieve the treatment target by being assigned to gain, maintain, or lose BCS groups. Cows in all treatment groups grazed an allowance of fresh pasture and were supplemented with pasture silage, corn silage, and palm kernel expeller. Estimated total DMI was $5.7 \pm 0.83$, $8.7 \pm 1.60$, and $13.4 \pm 2.90 \mathrm{~kg} / \mathrm{d}$ for lose, maintain, and gain BCS groups, respectively. Blood was sampled 
monthly to ensure metabolic indices of health were within normal ranges (Gribbles Veterinary Pathology, Hamilton, New Zealand). Following the completion of lactation, nonlactating cows grazed pasture and were offered a mix of pasture silage, corn silage, and palm kernel expeller to allow for cow maintenance and development of the gravid uterus (Mandok et al., 2013: average DMI $=8.0 \pm 1.05 \mathrm{~kg} \mathrm{DM} / \mathrm{d}$ ).

From $23 \pm 5.6 \mathrm{~d}$ precalving, cows were allocated to their assigned feeding level treatment. Cows were offered fresh pasture at 75,100 , or $125 \%$ of their estimated $\mathrm{ME}$ requirements $\left(1.05 \mathrm{MJ} / \mathrm{kg}\right.$ of $\mathrm{BW}^{0.75}$; Roche et al., 2005). To achieve different pasture allowances and, hence, DMI, different-sized areas were allotted to each treatment group precalving, with area size/group declining as cows calved and were removed from the treatment area. Area allocation $\left(\mathrm{m}^{2} / \mathrm{cow}\right)$ was calculated by multiplying pregrazing pasture mass per $\mathrm{m}^{2}$ by the desired allowance per cow. Daily group allocation was then calculated by multiplying the area allocation by the number of cows remaining in the precalving group. Precalving grazing areas averaged $40( \pm 6.8)$, $52( \pm 7.1)$, and $60( \pm 11.0) \mathrm{m}^{2} /$ cow per d for Feed75, Feed100, and Feed125, respectively.

The 6 treatments were grazed within the same paddock and separated by an electric fence to control pasture allowance/treatment. Back-grazing beyond the day's allocation was prevented using electric fences and the cows had access to water in their respective treatment areas. The pasture offered precalving consisted of $92.6( \pm 3.11) \%$ perennial ryegrass (Lolium perenne L.), $2.8( \pm 2.34) \%$ white clover (Trifolium repens), 2.5 $( \pm 1.69) \%$ weeds and other grasses (Dactylus glomerata, Holcus lanatus, and some Poa species), and 2.2 $( \pm 0.64) \%$ dead material on a DM basis. Nutrient composition of pasture offered is presented in Table 1.
As cows were grazed within the same paddock, pregrazing pasture height and mass did not differ between treatments. Average pregrazing pasture height was $9.1 \pm 1.7 \mathrm{~cm}(9.0 \pm 1.67,9.1 \pm 1.76$ and $9.2 \pm$ $1.99 \mathrm{~cm}$ for Feed75, Feed100, and Feed 125 treatment groups, respectively), whereas pregrazing pasture mass averaged 2,513 $\pm 385.8 \mathrm{~kg}$ of DM/ha $(2,429 \pm 407.3$, $2,482 \pm 430.2$, and $2,650 \pm 347.9 \mathrm{~kg}$ of DM for Feed75, Feed100, and Feed 125 treatment groups, respectively). Postcalving, cows from all 6 treatments were grazed together as a single herd and were offered a diet of fresh grazed pasture (average DMI $=12.4 \pm 0.8 \mathrm{~kg} / \mathrm{d}$ ), with corn silage (average DMI $=0.8 \pm 0.8 \mathrm{~kg} / \mathrm{d}$ ) and pasture silage (average DMI $=1.1 \pm 1.0 \mathrm{~kg} / \mathrm{d}$ ) as supplementary feeds. As cows were grazed within the same paddock, pregrazing pasture height and mass did not differ between treatments. Average pregrazing pasture height and mass were $10.8 \pm 0.9 \mathrm{~cm}$ and $3,041 \pm 360.3$ $\mathrm{kg} \mathrm{DM} / \mathrm{ha}$, respectively. The sward consisted of 91.8 $( \pm 4.74) \%$ perennial ryegrass (Lolium perenne L.), 1.6 $( \pm 2.33) \%$ white clover (Trifolium repens), $3.1( \pm 2.05) \%$ weeds and other grasses (Dactylus glomerata, Holcus lanatus, and some Poa species), and $3.5( \pm 2.97) \%$ dead material on a DM basis. The nutritive characteristics of the feeds offered pre- and postcalving are presented in Table 1.

\section{Milk, DMI, BCS, and BW}

Milk yield was determined daily from wk 1 to 12 (DeLaval, Tumba, Sweden). Milk was sampled weekly on consecutive afternoon and morning milkings and a composite sample analyzed for milk composition and SCC. Milk composition was determined in the weekly samples by infrared analysis (FT120, Foss Electric, Hillerød, Denmark). Somatic cells were enumerated us-

Table 1. Mean (SD in parentheses) nutrient composition (\% of DM, unless otherwise stated) and ME content of feeds offered to cows precalving and during early lactation

\begin{tabular}{|c|c|c|c|c|}
\hline \multirow[b]{2}{*}{ Item } & \multirow{2}{*}{$\begin{array}{c}\text { Precalving } \\
\text { Pasture }\end{array}$} & \multicolumn{3}{|c|}{ Lactating } \\
\hline & & Maize silage & Pasture & Pasture silage \\
\hline $\mathrm{CP}$ & $19.2(1.43)$ & $7.8(0.39)$ & $19.3(2.30)$ & $19.0(2.20)$ \\
\hline OM digestibility, $\%$ of OM & $91.3(1.97)$ & & $89.1(5.12)$ & \\
\hline DM digestibility & & & & $73.5(2.38)$ \\
\hline NDF & $40.4(2.71)$ & $39.2(2.97)$ & $43.7(3.46)$ & $49.0(2.05)$ \\
\hline $\mathrm{ADF}$ & $21.0(1.12)$ & $32.0(1.31)$ & $22.9(1.68)$ & $33.9(1.17)$ \\
\hline Lignin & $2.1(0.37)$ & & $2.1(0.29)$ & $5.9(0.41)$ \\
\hline NFC & $14.3(1.74)$ & $35.3(2.29)$ & $12.8(2.62)$ & $2.0(1.68)$ \\
\hline Lipid & $3.0(0.21)$ & $3.8(0.39)$ & $2.5(0.54)$ & $3.3(0.22)$ \\
\hline $\mathrm{ME}, \mathrm{MJ} / \mathrm{kg}$ of DM & $13.0(0.25)$ & $10.0(0.13)$ & $12.7(0.56)$ & $11.8(0.38)$ \\
\hline Ash & $8.8(0.46)$ & $4.3(0.17)$ & $8.8(0.60)$ & $10.3(0.60)$ \\
\hline DCAD, mEq/kg DM & $628(40.2)$ & $251(17.1)$ & $626(65.9)$ & $693(19.4)$ \\
\hline Lactic acid & & $3.6(0.71)$ & & $5.9(0.59)$ \\
\hline $\mathrm{NH}_{4} \mathrm{~N}, \% \mathrm{~N}$ & & $9.2(0.56)$ & & $16.5(1.47)$ \\
\hline $\mathrm{pH}$ & & $3.7(0.03)$ & & $3.7(0.22)$ \\
\hline
\end{tabular}


ing an electronic fluorometric cell-counting technique (Fossomatic, Foss Electric) by LIC Ltd. (Hamilton, New Zealand). Dry matter intake was estimated as the difference between pre- and postgrazing mass multiplied by the area allocated/cow.

Weekly, following the morning milking or at approximately $0800 \mathrm{~h}$ during the nonlactating period, BW was recorded and BCS determined by a minimum of 3 experienced assessors (BCS was assessed on a scale of 1 to 10 , where 1 is emaciated and 10 obese; Roche et al., 2004). All BCS assessors were trained and recalibrated at the start of the experiment following the procedures set out in Macdonald and Roche (2004). The interobserver variance component for BCS estimates was 0.05 $( \pm 0.2)$.

\section{Blood and Liver Tissue Sampling and Analyses}

Blood was sampled by coccygeal venipuncture weekly before and after calving and on $\mathrm{d} 0,1,2,3$, and 4 relative to calving. Blood was collected in evacuated blood tubes containing a lithium heparin anticoagulant; samples were placed immediately into iced water and centrifuged within $30 \mathrm{~min}$ at $1,500 \times g$ for $12 \mathrm{~min}$ at $4^{\circ} \mathrm{C}$. Following centrifugation, aspirated plasma was stored at $-20^{\circ} \mathrm{C}$ until assayed.

Blood metabolite and the liver TAG assays were performed by Gribbles Veterinary Pathology Ltd. Blood metabolites were assayed using colorimetric techniques at $37^{\circ} \mathrm{C}$ with a Hitachi Modular P800 analyzer (Roche Diagnostics, Indianapolis, IN). Roche reagent kits were used to measure plasma concentrations of albumin (g/L; bromocresol green reaction at $\mathrm{pH}$ 4.1), BHBA (mmol/L; reduction of NAD to NADH during oxidation of D-3-hydroxybutyrate to acetoacetate), $\mathrm{Ca}(\mathrm{mmol} / \mathrm{L}$; o-cresolphthalein complexone method), $\mathrm{Mg}$ ( $\mathrm{mmol} / \mathrm{L}$; xylidyl blue reaction), and total protein $(\mathrm{g} / \mathrm{L}$; biuret method). Plasma globulin was calculated as the difference between total protein and albumin. Plasma NEFA concentrations $(\mathrm{mmol} / \mathrm{L})$ were measured using Wako Chemicals (Osaka, Japan) kit NEFA HR2 measuring oxidative condensation of 3 -methyl- $N$-ethyl- $N-\beta$ hydroxyethyl aniline with 4-aminoantipyrine. The interand intraassay coefficients of variation for assays were between 0.8 and $5.3 \%$, and 0.5 and $15 \%$, respectively.

Liver TAG content was analyzed in biopsy samples (wk 1, 2, and 4 postcalving) by modifying the procedure described in the Wako LabAssay Triglyceride Kit (Wako Chemicals USA Inc., Richmond, VA). Briefly, approximately $50 \mathrm{mg}$ of liver tissue was finely chopped using a sterile scalpel blade and homogenized in $1 \mathrm{~mL}$ of $5 \%$ Triton-X100 in water. The homogenized tissue was slowly heated in a water bath $\left(80-100^{\circ} \mathrm{C}\right)$ for 2 to
5 min or until the Triton X-100 131 appeared cloudy. After cooling the mixture at room temperature, the heating process was repeated one more time to solubilize all TAG into solution. The samples were vortexed and centrifuged at $2,000 \times g$ for 5 min to remove any insoluble material. The supernatant was collected in sterile $1.5-\mathrm{mL}$ microfuge tubes and stored at $-80^{\circ} \mathrm{C}$. Approximately $50 \mu \mathrm{L}$ of sample was diluted 10-fold with distilled water before the TAG assay. The TAG analysis was performed using the standard procedure provided in the Wako LabAssay Triglyceride Kit.

Plasma IL-1 $\beta$ and IL-6 were analyzed by commercially available bovine ELISA kits (Pierce, Thermo Scientific, Rockford, IL, and GenWay Biotech Inc., San Diego, CA). These kits are designed for the analysis of cell culture supernatants. Validation of the kit for bovine plasma was performed via spike-in recovery assessment (R\&D Systems Inc., Minneapolis, MN; spike and recovery Immunoassay Sample Validation Protocol) and linearity testing. A total of $100 \mu \mathrm{L}$ of undiluted sample was used to perform each assay. Absorbance was read according to the manufacturer's protocol with a microplate spectrophotometer (Biotek Instruments, Winooski, VT). A 7-point standard curve with a 1:2 dilution factor (plus zero standard) was generated for each plate and a 4-parameter logistic curve was used to fit the data [Gen5 (v2.0) software; Biotek Instruments]. Haptoglobin (Hp) was measured by a commercially available bovine ELISA kit (Life Diagnostics Inc., West Chester, PA). Following the manufacturer's protocol, samples were diluted 1:2,000 with kit reagents. A total of $100 \mu \mathrm{L}$ of diluted sample was used to perform the assay. Absorbance was read according to the manufacturer's protocol with a microplate spectrophotometer (Biotek Instruments). A 6-point standard curve with a 1:2 dilution factor (plus a zero standard) was generated and a linear curve was fitted to the data using Excel (Microsoft Corp., Redmond, WA). Cholesterol was measured through a commercially available fluorimetric kit (Cayman Chemical Company, Ann Arbor, MI). Samples were diluted 1:200 with kit reagents. A total of $50 \mu \mathrm{L}$ of diluted sample was used to perform the assay. Fluorescence was measured with a fluorimetric microplate reader (Biotek Instruments). A 7-point standard curve with a 1:2 dilution factor (plus a zero standard) was generated and a linear curve was fitted to the data using Excel (Microsoft Corp.). For IL-1 $\beta$, IL-6, and Hp, the intraassay CV were 4,7 , and $3 \%$, respectively, and the interassay $\mathrm{CV}$ were 9,14 , and $6 \%$, respectively.

Total antioxidant capacity (TAC) of plasma was assayed through a commercially available colorimetric kit (Cayman Chemical Company). Samples were diluted 1:20 with kit reagents. A total of $10 \mu \mathrm{L}$ of diluted 
sample was used to perform the assay. Absorbance was read according to the manufacturer's protocol with a microplate spectrophotometer (Biotek Instruments). A 7-point standard curve with a 1:2 dilution factor (plus a zero standard) was generated and a linear curve was fitted to the data using Excel (Microsoft Corp.). Reactive oxygen species (ROS) were measured through a commercially available fluorimetric kit (Cell Biolabs Inc., San Diego, CA). A total of $50 \mu \mathrm{L}$ of undiluted sample was used to perform the assay. Fluorescence was measured with a fluorimetric microplate reader (Biotek Instruments). A 7-point standard curve, serially diluted according to the kit protocol, (plus a zero standard) was generated and a linear curve was fitted to the data using Excel (Microsoft Corp.).

\section{Uterine Cytology, Metricheck Sampling for Endometritis, and Milk Progesterone}

Between 11 and 17 DIM and 32 and 39 DIM, samples of endometrial fluid were collected from all cows for cytological examination using the technique described by Burke et al. (2010). Material recovered from the endometrial cytobrush was smeared onto microscope slides and air-dried. Slides were fixed and stained (Diff-Quik, Dade Behring, Newark, DE) within 1 h of collection and examined by a veterinary pathologist (IVABS, Massey University, Palmerston North, New Zealand). Areas of each slide that contained small clusters of epithelial cells (5-20 cells per cluster) were preferentially selected and all intact identifiable nucleated cells were counted in these fields. Approximately 200 nucleated cells per slide were enumerated, with PMNL distinguished from non-PMNL cells, to allow the proportions of nucleated cells that were PMNL to be calculated. The PMNL threshold for classifying cows with subclinical endometritis was $\geq 14 \%$ at the $\mathrm{d} 11-17$ cytological examination or $\geq 7 \%$ at the $\mathrm{d}$ 32-39 cytological examination (Priest et al., 2013).

On completion of endometrial sampling, vaginal content was sampled using a Metricheck device (Simcro Tech Ltd., Hamilton, New Zealand); this device consists of a 40-mm-diameter hemisphere of silicon attached to a 500-mm-long stainless steel rod. The vaginal content was scored ( 0 being no sample, 1 being clear mucus, and 5 being purulent pus; McDougall et al., 2007). Cows were identified with purulent vaginal discharge (endometritis) when the vaginal mucus was scored as $>1$ (i.e., $2,3,4$, or 5 ) and defined as having normal vaginal discharge when scored $\leq 1$ (i.e., 0 and 1 ; McDougall et al., 2007).

Progesterone was measured in milk collected twice weekly (a.m. milking on each Tuesday and Friday) from
$14 \mathrm{~d}$ after calving to $81 \pm 10.2$ DIM using a commercial kit (Progesterone Coat-A-Count; Siemens, Los Angeles, $\mathrm{CA}$ ). The average intraassay $\mathrm{CV}$ for the high and low controls was 11.5 and $20.7 \%$, respectively, the average interassay CV for the high and low controls was 9.4 and $8.7 \%$, respectively, and the minimum detectable level was $0.1 \mathrm{ng} / \mathrm{mL}$. The postpartum anovulatory interval (PPAI) was defined as the interval from calving to the first of 2 consecutive blood samples where plasma progesterone concentration was $\geq 2 \mathrm{ng} / \mathrm{mL}$. The rebreeding period commenced $75 \mathrm{~d}$ from the mean calving date for the herd and continued for $10 \mathrm{wk}$. Following the breeding period, cows were examined twice by transrectal ultrasonography to determine their pregnancy status and conception date through fetal aging.

\section{Statistical Analysis}

Statistical analyses were performed using either Genstat 14.1 (VSN International, Hemel Hempstead, UK) or SAS 9.3 (SAS Institute Inc., Cary, NC) and significance was declared if $P \leq 0.05$.

Milk, BW, and BCS Data. A repeated measurement analysis of the milk production data from the first 12 wk of lactation was undertaken using cubic smoothing splines within the linear mixed model framework described by Verbyla et al. (1999). Precalving BCS, precalving feeding level, the interaction of BCS and feeding level, the linear trend of week, and interactions of the linear trend of week with BCS and feeding level were included in the model as fixed effects and cow, linear trend of week within cow, spline, the interaction of cow with spline, and the interaction of BCS and feeding level treatments with spline were included as random effects. Residual maximum likelihood in Genstat 14.1 was used to fit these models.

Average weekly production for each cow was also calculated for wk 1-6, 7-12, and 1-12 and analyzed using mixed models, with precalving BCS, precalving feeding level, and their interaction as fixed effects and cow as the random effect. Production from the first 2 wk in February before start of treatments was included as a covariate in all analyses.

Body weight and BCS were analyzed for 2 periods: wk -6 to wk -1 relative to calving and wk 2 to wk 12 postcalving. Cubic smoothing splines were fitted initially to determine interactions between BCS and feeding level treatments and time. The data were then analyzed for each week relative to calving to explore the interaction with time using mixed models, with precalving BCS, precalving feeding level, and the interaction of BCS and feeding level as fixed effects and cow as the random effect. 
Blood and Liver TAG Data. Blood data were divided into 3 periods (i.e., weekly precalving, daily postcalving from d $0-4$, and weekly postcalving) and each period analyzed separately. Data were subjected to repeated-measures ANOVA using mixed models (PROC MIXED, SAS 9.3). Statistical models included precalving BCS, precalving feeding level, and time (month, week, or day, as appropriate), and their interactions as fixed effects, and cow as the random effect. Covariates and blocking factors included baseline blood results (February for weekly precalving, $\mathrm{d}-7$ for daily and weekly postcalving), calving date within the herd (difference, in days, between actual calving date and the earliest calving date), cow breed (Holstein-Friesian, Jersey, Holstein-Friesian $\times$ Jersey), and age group (3 or $3+\mathrm{yr}$ ). Data were $\log _{10}$ transformed if required to achieve homogeneity of variance. For blood BHBA, blood $\mathrm{Ca}$, blood $\mathrm{Hp}$, and liver TAG, the percentages of samples with low, medium, and high physiological concentration were subjected to chi-squared test of association (PROC FREQ, SAS 9.3).

Reproduction Data. Metricheck score and PMNL percentage were subjected to repeated-measures ANOVA using a mixed models approach (PROC MIXED, SAS 9.3). Statistical models included precalving BCS, precalving feeding level, week, and their interactions as fixed effects and cow as a random effect. Breed and age group were used as blocking factors and calving date within the herd (difference between actual calving date and the earliest calving date in days) as a covariate. $\log _{10}$ and probit transformations were used where appropriate to achieve homogeneity of variance. The percentage of cows identified with purulent vaginal discharge or subclinical endometritis was subjected to chi-squared test of association.

The percentage of anestrous cows was subjected to chi-squared test of association. For cows that had ovulated, the interval from calving to ovulation was subjected to 2-way ANOVA with precalving BCS, precalving feeding level, and their interaction included as fixed effects, with cow breed, and age group as blocking factors, and calving date within the herd (difference between actual calving date and the earliest calving date in days) as a covariate. Data were $\log _{10}$ transformed before analysis to achieve homogeneity of variance. For cows that ovulated and cows that were pregnant, survival analysis (PROC LIFETEST, SAS 9.3) was used to analyze the effect of precalving BCS or precalving feeding level on the time to first ovulation postcalving and conception. Season, breed (0, 50 or $100 \%$ HolsteinFriesian), and age (3 vs. $3+$ yr) were used as covariates. Parameters of reproductive performance were analyzed using GLM (PROC GLIMMIX, SAS 9.3) to estimate the effects of precalving BCS, precalving feeding level, and their interactions, after correcting for breed, age group, and season.

\section{RESULTS}

As per the experimental design and the different area allocations/cow precalving, precalving DMI increased with increasing pasture allowance. On average, in Feed75, Feed100, and Feed125 treatments, respectively, BCS4 cows consumed $6.6( \pm 1.1), 8.4( \pm 1.1)$, and 9.8 $( \pm 1.5) \mathrm{kg}$ of $\mathrm{DM} / \mathrm{d}$ precalving and BCS5 cows consumed $6.9( \pm 1.2), 9.2( \pm 1.3)$, and $10.7( \pm 1.9) \mathrm{kg}$ of $\mathrm{DM} / \mathrm{d}$. In BW terms, these DMI were 1.3, 1.6, and $1.8 \%$ of BW for BCS4 cows and 1.2, 1.6, and $1.8 \%$ of BW for BCS5 cows in Feed75, Feed100, and Feed125 treatments, respectively. These equated to 86, 109, and $127 \mathrm{MJ}$ of ME/cow per day for BCS4 cows and 90, 120, and $139 \mathrm{MJ}$ of ME/cow per day for BCS5 cows, respectively. Precalving, postgrazing residual pasture height $(3.4 \pm 0.46,3.6 \pm 0.64$, and $3.8 \pm 0.24 \mathrm{~cm}$ for Feed75, Feed100, and Feed125, respectively) and mass (717 \pm $31.6,840 \pm 156.8$, and $900 \pm 87.0 \mathrm{~kg}$ of $\mathrm{DM} / \mathrm{ha}$ for Feed75, Feed100, and Feed125, respectively) increased $(P<0.001)$ with pregrazing pasture allowance.

\section{Production, BCS, BW, and Reproduction Variables}

Milk Production. Effects of precalving BCS and precalving feeding level on milk production and yield of milk fat, protein, and lactose are presented in Table 2. Milk yield and yield of milk components were lower $(P<0.01)$ in BCS4 than in BCS5 cows. Over the first 12 wk in milk, BCS5 cows produced $145 \mathrm{~kg}$ more milk and $9.0,3.5$, and $7.5 \mathrm{~kg}$ more milk fat, protein, and lactose, respectively, than did BCS4 cows. Precalving level of feeding did not significantly affect any of the milk production variables. Interestingly, we detected an interaction between precalving BCS and level of feeding for yields of milk $(P=0.06)$, milk fat $(P<0.01)$, milk protein $(P=0.09)$, and lactose $(P<0.05)$ in wk 12 postcalving; this interaction reflects lower daily milk yields in BCS5 cows in the Feed125 treatment than in BCS5 cows in the other 2 feeding level treatments (24.1, 24.4, and $23.1 \mathrm{~kg}$ of milk in Feed75, Feed100, and Feed 125, respectively), but no effect of feeding level in the BCS4 cows in this week.

$\boldsymbol{B} \boldsymbol{C S}$ and $\boldsymbol{B} \boldsymbol{W}$. As per the experimental design, cows in the BCS4 group calved at 1 BCS unit thinner $(P<0.001)$ than cows in the BCS5 herd [BCS $1 \mathrm{wk}$ precalving $=4.1$ and 5.1, respectively; standard error of the difference in means (SED) $=0.03]$; furthermore, BCS4 cows remained thinner $(P<0.001)$ during the 
Table 2. Effects of BCS 1 mo precalving and level of feeding before calving ${ }^{1}$ on average daily yield of milk and milk components and the average milk composition of cows during the first 12 wk of lactation

\begin{tabular}{|c|c|c|c|c|c|c|c|c|c|c|}
\hline Item & BCS4 & BCS5 & $\mathrm{SED}^{2}$ & Feed75 & Feed100 & Feed125 & SED & \multicolumn{3}{|c|}{$P$-value } \\
\hline Milk & 22.9 & 24.6 & 0.38 & 23.5 & 24.1 & 23.8 & 0.47 & $<0.001$ & 0.51 & 0.49 \\
\hline Fat & 0.98 & 1.09 & 0.02 & 1.03 & 1.03 & 1.05 & 0.02 & $<0.001$ & 0.41 & 0.32 \\
\hline Protein & 0.81 & 0.85 & 0.01 & 0.83 & 0.83 & 0.83 & 0.02 & $<0.001$ & 0.93 & 0.50 \\
\hline Lactose & 1.11 & 1.20 & 0.02 & 1.14 & 1.17 & 1.16 & 0.02 & $<0.001$ & 0.48 & 0.48 \\
\hline Protein & 3.54 & 3.47 & 0.024 & 3.53 & 3.47 & 3.52 & 0.030 & $<0.01$ & 0.10 & 0.75 \\
\hline Lactose & 4.86 & 4.88 & 0.011 & 4.86 & 4.88 & 4.89 & 0.014 & 0.06 & 0.08 & 0.98 \\
\hline
\end{tabular}

${ }^{1}$ Cows were either a BCS of 4 or 5 and offered 75, 100, and 125\% of their energy requirements (Roche et al., 2005; Feed75, Feed100, and Feed125, respectively) for $23 \pm 5.6 \mathrm{~d}$ precalving. BCS was measured on a 1-10 scale, where 1 is emaciated and 10 is obese (Roche et al., 2004).

${ }^{2} \mathrm{SE}$ of the difference.

first 12 wk of lactation. However, the difference in BCS diminished with time (Figure 1; BCS 12 wk postcalving $=4.1$ and 4.2 , respectively; $\mathrm{SED}=0.03)$. This effect of precalving BCS on energy stores was also reflected in calving BW and postcalving BW loss. Cows in the BCS4 group weighed $54 \mathrm{~kg}$ less $(P<0.001)$ than cows in the BCS5 herd at 1 wk precalving and, although they remained lighter $(P<0.001)$ during the first 12 wk of lactation, the difference diminished to $15 \mathrm{~kg}$ at 12 wk postcalving (Figure 1). There was a precalving BCS $\times$ feeding level interaction $(P<0.05)$ in BCS in wk 4 postcalving and a trend $(P<0.1)$ for an interaction in wk 3. This reflected a lack of precalving feeding level effect on BCS change in BCS4 cows (BCS unit loss/d for wk 2,3 , and $4=-0.23,-0.19$, and $-0.20 \times 10^{-2}$ in Feed75, Feed100, and Feed125 cows, respectively), but a greater loss of BCS in Feed100 and Feed125 cows than Feed75 cows in the BCS5 treatment (BCS unit loss/d for wk 2,3 , and $4=-1.14,-1.45$, and $-1.35 \times 10^{-2}$ in Feed75, Feed100, and Feed125 cows, respectively).

Reproduction. The proportion of cows with clinical endometritis, as categorized by the consistency of the vaginal mucous in a Metricheck examination, or subclinical endometritis, as categorized by cytological examination of PMNL\% in a uterine swab, 2 or $5 \mathrm{wk}$ postcalving are presented in Table 3 . Uterine health improved in both measures with time, but we observed no effect of either precalving BCS or feeding level nor a precalving $\mathrm{BCS} \times$ feeding level interaction on either measure of uterine health. The cumulative proportion of cows cycling with increasing DIM is presented in Figure 2. Cows in the BCS4 group at calving had longer PPAI $(P<0.01 ; 36$ vs. $45 \mathrm{~d}$; SED $=3.6)$ than those in BCS5, but there was no effect of treatment on any of the other reproduction variables measured (Table 4). Precalving feeding level did not affect the cumulative proportion of cows cycling with increasing DIM, nor did it affect the PPAI (40, 44, and $39 \mathrm{~d}$ for Feed75, Feed100 and Feed125, respectively; SED $=3.9$ ) or any of the other reproduction variables measured.

\section{Blood Indicators of EBAL, and Blood Proteins and Immunomodulatory Factors}

$\boldsymbol{E B} \boldsymbol{A} \boldsymbol{L}$. Precalving, cows in the BCS5 group had greater plasma NEFA $(P<0.01)$ and $\operatorname{BHBA}(P<$ $0.05)$ concentrations than BCS4 cows and concentrations of both metabolites increased linearly $(P<0.01)$ with declining feed intake (Figure 3 ). There was an interaction $(P<0.05)$ between BCS and feeding level in plasma BHBA concentration precalving, with the increase in BHBA in the Feed75 group greater $(0.16$ $\mathrm{mmol} / \mathrm{L}$ ) in the BCS5 group than in the BCS4 group (0.09 mmol/L).

Postpartum, blood NEFA concentrations peaked in the first week postcalving and declined until approximately 42 DIM, when the NEFA concentration reached a plateau in all treatments. In comparison, plasma BHBA concentrations rose to a peak in the first week postcalving and remained high until 6 wk postcalving, at which point concentrations declined. After calving, blood NEFA and BHBA concentrations increased with precalving BCS and feeding level. During the period immediately postcalving (d 0-4), blood NEFA concentrations were $37 \%$ greater in BCS5 cows than in BCS4 cows and were 10 and $13 \%$ greater in Feed100 and Feed125 cows than in Feed75 cows, respectively. The effect of precalving treatments on blood NEFA continued for $70 \mathrm{~d}$ postcalving, when measurements ceased; on average, from wk 1 to 10 postcalving, blood NEFA concentrations in BCS5 cows were $53 \%$ greater than in BCS4 cows and 9 and 17\% greater in Feed100 and 
Feed125 cows than Feed75 cows, respectively. During the $5 \mathrm{~d}$ immediately postcalving, blood BHBA concentrations were $17 \%$ greater $(P<0.001)$ in BCS5 cows than in BCS4 cows and 5 and $12 \%$ greater $(P<0.05)$ in Feed100 and Feed125 cows than in Feed75 cows, respectively. Blood BHBA concentrations remained 30 to $50 \%$ higher in BCS5 cows until $42 \mathrm{~d}$ postcalving, at which time treatment differences were no longer evident. Although Feed125 had greater $(P=0.07)$ BHBA concentrations than Feed75 during the first $10 \mathrm{wk}$ postcalving, the effect was not consistently significant each week. The proportion of cows regarded as ketotic (i.e., BHBA $>1.2 \mathrm{mmol} / \mathrm{L}$ ) was greater in BCS5 cows $(5-10 \%)$ than BCS4 cows $(<3 \%)$, but was not affected by precalving feeding level. The highest proportion of cows with BHBA $>1.2 \mathrm{mmol} / \mathrm{L}$ was detected on $\mathrm{d}$ 14 postcalving, with $8.3 \%$ of cows in BCS5 and $0 \%$ of BCS4 cows in this category.

Liver TAG postcalving increased with precalving BCS and there was an interaction between BCS and DIM in liver TAG, because of a $19 \%$ increase in TAG between wk 1 and 2 in BCS5 cows (average TAG = $4.7,5.6$, and $5.6 \mathrm{~g} / \mathrm{g}$ of wet weight in wk 1,2 , and 4 , respectively) but not $\mathrm{BCS} 4$ cows (average $\mathrm{TAG}=1.9$, 2.0 , and $1.7 \mathrm{~g} / \mathrm{g}$ of wet weight in wk 1,2 , and 4 , respectively). The proportion of cows with $<5 \%, 5-10 \%$, and $>10 \%$ liver fat was also affected by precalving BCS. On average, 96, 4, and $0 \%$ of BCS4 cows and 49 , 39 , and $12 \%$ of BCS5 cows were in these categories of liver fat infiltration, respectively. Liver TAG was not
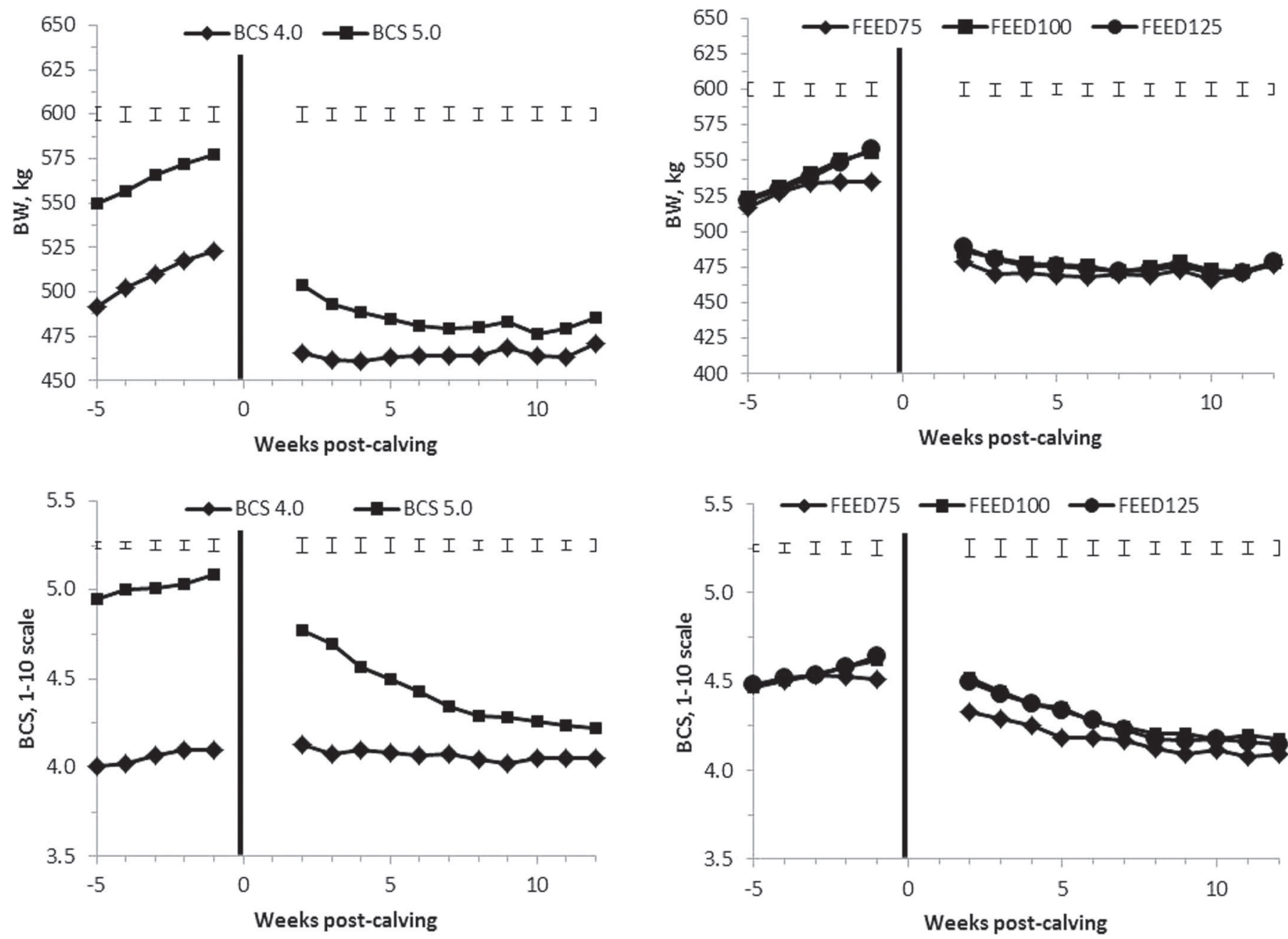

Figure 1. Effects of BCS 1 mo precalving and level of feeding before calving on BW and BCS change pre- and postcalving. Cows were either a BCS of 4 or 5 and offered 75,100 , and $125 \%$ of their energy requirements (Roche et al., 2005; Feed75, Feed100, and Feed125, respectively) for $23 \pm 5.6$ d precalving. BCS was measured on a 1-10 scale, where 1 is emaciated and 10 is obese (Roche et al., 2004). There was no interaction; therefore, main effects are presented. Error bars represent SE of the difference. 

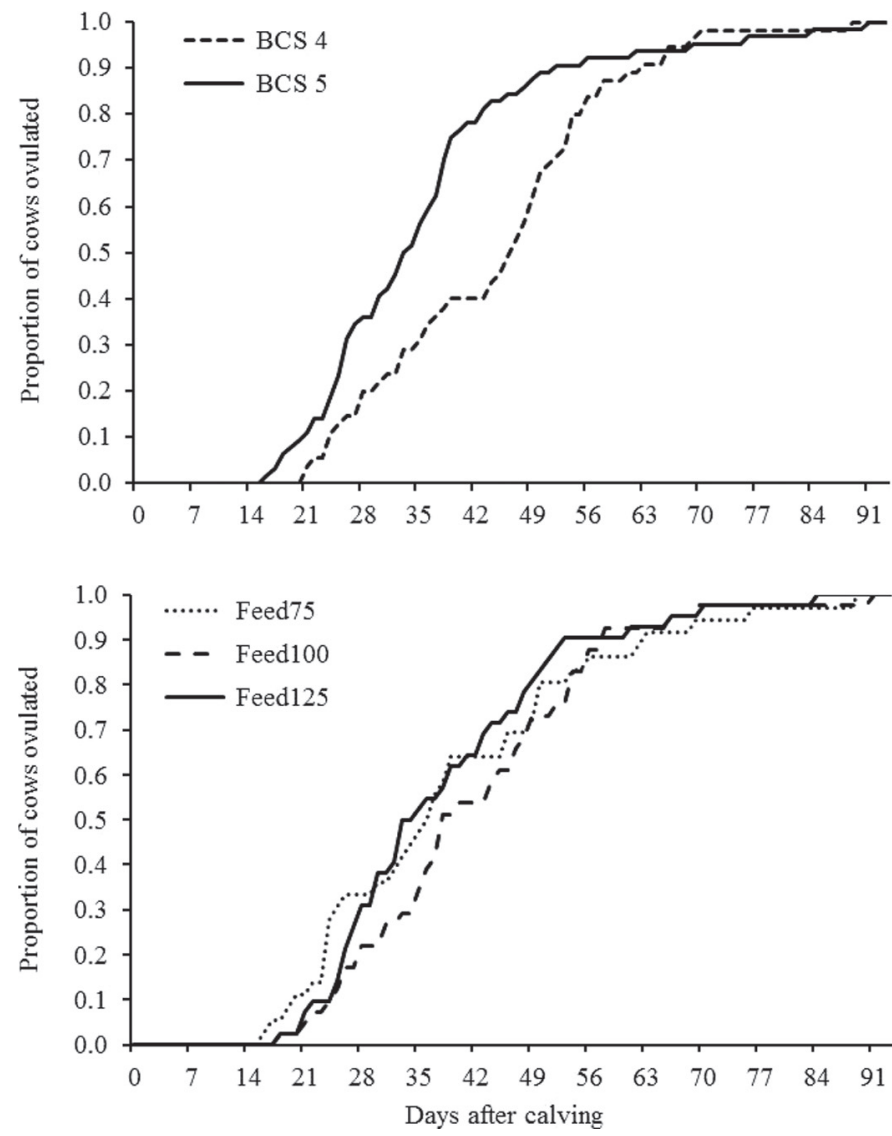

Figure 2. Effects of BCS 1 mo precalving and level of feeding before calving on the cumulative proportion of cows ovulated postcalving. Cows were either a BCS of 4 or 5 and offered 75, 100, and $125 \%$ of their energy requirements (Roche et al., 2005; Feed75, Feed100, and Feed 125 , respectively) for $23 \pm 5.6 \mathrm{~d}$ precalving. BCS was measured on a $1-10$ scale, where 1 is emaciated and 10 is obese (Roche et al., 2004). affected by precalving level of feeding and we detected no significant difference in the proportion of cows in the categories of liver fat infiltration $(77,16$, and $7 \%$ of cows in Feed75; 70, 28, and 2\% of cows in Feed100, and 71,21 , and $8 \%$ of cows in Feed125, respectively, were categorized as having $<5 \%, 5-10 \%$, and $>10 \%$ liver fat on a $\mathrm{g} / \mathrm{g}$ of wet weight basis).

Blood Proteins. The blood albumin concentration and the albumin:globulin ratio were used as indicators of liver function. Blood albumin concentrations were greater in BCS5 cows precalving (35.0 and $33.5 \mathrm{~g} / \mathrm{L}$ in BCS5 and BCS4 cows, respectively) and until $28 \mathrm{~d}$ postcalving (36.4 and $35.2 \mathrm{~g} / \mathrm{L}$, respectively). Feed125 cows had lower blood albumin concentrations on $\mathrm{d} 0$ and $\mathrm{d}$ 1 postcalving $(0.6-0.8 \mathrm{~g} / \mathrm{L})$. Neither globulin nor total protein concentration was affected by precalving BCS or feeding level. Albumin:globulin ratio was greater in BCS5 cows. There was, however, a BCS $\times$ feeding level interaction $(P<0.01)$ in both albumin concentration and the albumin:globulin ratio postcalving. In the days immediately following calving, blood albumin concentration was $0.4 \mathrm{~g} / \mathrm{L}$ greater in BCS4-Feed125 cows than BCS4-Feed75 cows but $0.5 \mathrm{~g} / \mathrm{L}$ greater in BCS5-Feed75 cows than BCS5-Feed 125 cows. This effect was mirrored in the albumin:globulin ratio, with BCS4-Feed125 cows having a greater ratio than BCS4-Feed75 cows (1.06 and 1.03), whereas BCS5-Feed75 cows had a greater ratio than BCS5-Feed125 cows (1.09 and 1.03). This interaction continued until 8 wk postcalving (Figure 4).

Immunomodulatory Factors. The effects of precalving BCS and feeding level on circulating concentrations of immunomodulatory compounds are presented in Figures 5 and 6 . The relationships were complicated

Table 3. Effects of BCS 1 mo precalving and level of feeding before calving ${ }^{1}$ on cows (\%) with clinical $^{2}$ or $^{2}$ subclinical $^{3}$ endometritis at 2 and 5 wk postcalving

\begin{tabular}{|c|c|c|c|c|c|c|c|c|}
\hline \multirow[b]{3}{*}{ Item } & \multicolumn{4}{|c|}{ Clinical endometritis ${ }^{2}$} & \multicolumn{4}{|c|}{ Subclinical endomentritis ${ }^{3}$} \\
\hline & \multicolumn{2}{|c|}{$2 \mathrm{wk}$} & \multicolumn{2}{|c|}{$5 \mathrm{wk}$} & \multicolumn{2}{|c|}{$2 \mathrm{wk}$} & \multicolumn{2}{|c|}{$5 \mathrm{wk}$} \\
\hline & $\leq 1$ & $>1$ & $\leq 1$ & $>1$ & $<14 \%$ & $\geq 14 \%$ & $<7 \%$ & $\geq 7 \%$ \\
\hline \multicolumn{9}{|l|}{$\overline{\mathrm{BCS}}$} \\
\hline 4 & 60 & 40 & 92 & 8 & 29 & 71 & 61 & 39 \\
\hline 5 & 67 & 33 & 92 & 8 & 28 & 72 & 61 & 39 \\
\hline \multicolumn{9}{|l|}{ Feed } \\
\hline 75 & 68 & 32 & 87 & 13 & 30 & 70 & 57 & 43 \\
\hline 100 & 60 & 40 & 92 & 8 & 23 & 77 & 60 & 40 \\
\hline 125 & 61 & 39 & 96 & 4 & 33 & 67 & 65 & 34 \\
\hline
\end{tabular}

${ }^{1}$ Cows were either a BCS of 4 or 5 and offered 75,100 , and $125 \%$ of their energy requirements (Roche et al., 2005; Feed75, Feed100, and Feed125, respectively) for $23 \pm 5.6 \mathrm{~d}$ precalving; BCS was measured on a 1-10 scale, where 1 is emaciated and 10 is obese (Roche et al., 2004).

${ }^{2}$ Cows were classified as having a normal vaginal discharge when scored 0 or 1 or as presenting with clinical endometritis when the vaginal mucus was scored 2, 3, 4, or 5 using the Metricheck scoring system (McDougall et al., 2007).

${ }^{3}$ The PMNL threshold for classifying cows with subclinical endometritis was $\geq 14 \%$ at wk 2 or $\geq 7 \%$ at wk 5 (Priest et al., 2013). 

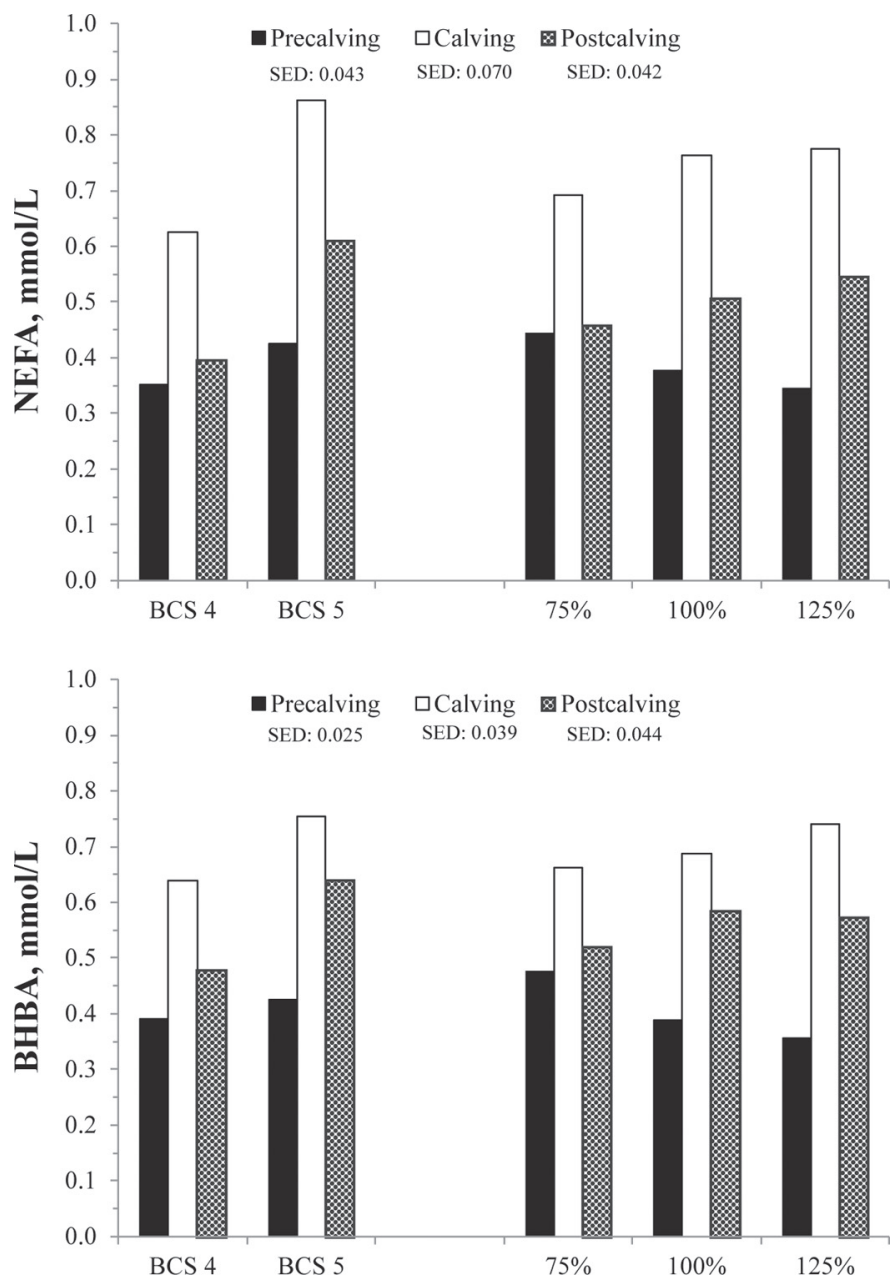

Figure 3. Effects of BCS 1 mo precalving and level of feeding before calving on plasma NEFA and BHBA concentration precalving, during the period between calving and $4 \mathrm{~d}$ postcalving (i.e., calving), and during the first $70 \mathrm{~d}$ postcalving. Cows were either a BCS of 4 or 5 and offered 75,100 , and $125 \%$ of their energy requirements (Roche et al., 2005) for $23 \pm 5.6 \mathrm{~d}$ precalving. BCS was measured on a 1-10 scale, where 1 is emaciated and 10 is obese (Roche et al., 2004). There was no interaction; therefore, main effects are presented. SED $=$ SE of the difference.

by interactions between BCS, feeding level, and time, but, in general, concentrations of factors positively associated with inflammation and metabolic stress (IL-6, IL-1 $\beta$, ROS) were elevated immediately postcalving in BCS4 cows feed restricted before calving, but the effect was only evident during the short period immediately postcalving (i.e., d $0-4$; BCS $\times$ Feed $\times$ Time, $P<0.05$ ). In fact, if data from the BCS4-Feed75 group are omitted, ROS concentrations were greater in BCS5 cows compared with BCS 4 cows. In comparison, factors negatively associated with inflammation and metabolic stress (e.g., TAC, cholesterol) were lower in concentration in blood immediately postcalving in BCS4 cows restricted before calving $(\mathrm{BCS} \times$ Feed $\times$ Time, $P<$

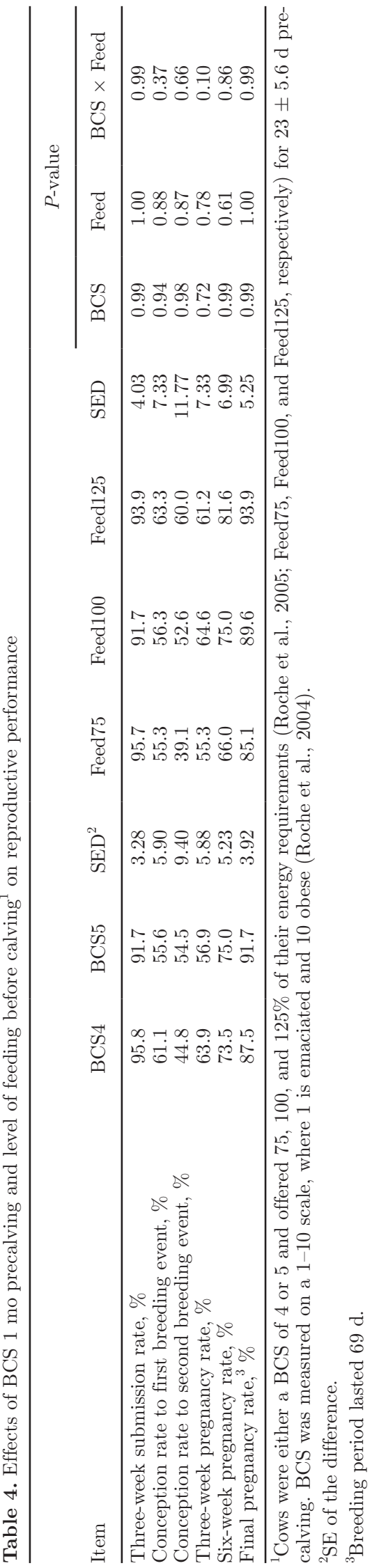

Journal of Dairy Science Vol. 98 No. 10, 2015 

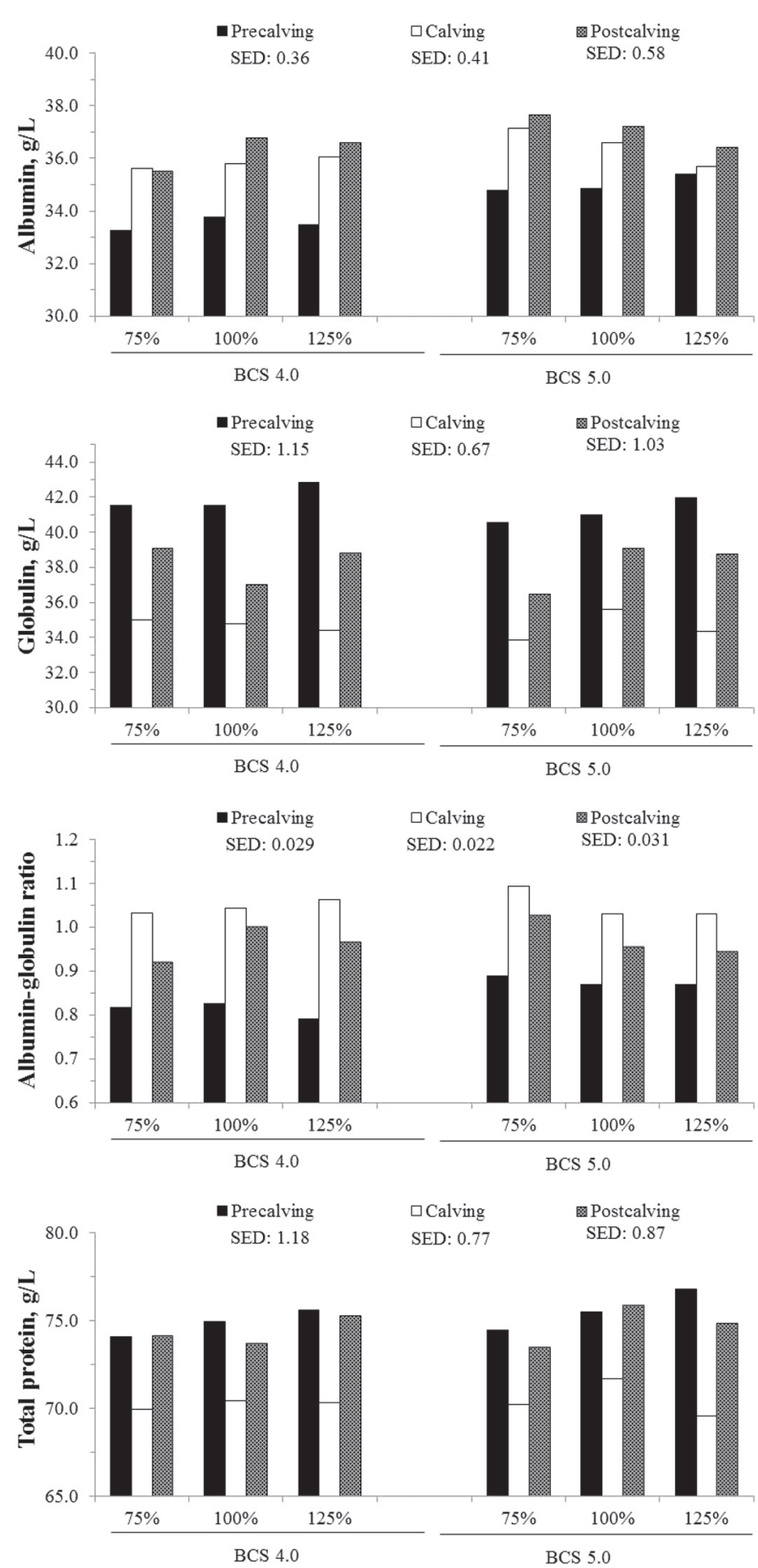

Figure 4. Effects of BCS 1 mo precalving and level of feeding before calving on plasma protein concentrations precalving, during the period between calving and $4 \mathrm{~d}$ postcalving (i.e., calving), and during the first $70 \mathrm{~d}$ postcalving. Cows were either a BCS of 4 or 5 and offered 75,100 , and $125 \%$ of their energy requirements (Roche et al., 2005 ) for $23 \pm 5.6 \mathrm{~d}$ precalving. BCS was measured on a 1-10 scale, where 1 is emaciated and 10 is obese (Roche et al., 2004). SED = SE of the difference.
0.05). Level of feeding did not affect concentrations of these immunomodulatory factors in BCS5 cows. We detected no consistent effect of precalving feeding level in BCS5 cows immediately postcalving. Although not statistically significant, blood concentration of $\mathrm{Hp}$ after calving was greater in BCS4-Feed75 cows than the other BCS4 feeding level treatments, but Hp concentration appeared to increase immediately postcalving with increasing feeding level precalving if BCS4-Feed75 is omitted.

Blood Mineral Concentrations. Effects of precalving BCS and level of feeding on periparturient blood $\mathrm{Ca}$ and $\mathrm{Mg}$ concentrations are presented in Figure 7. Blood $\mathrm{Ca}$ concentrations during the $4 \mathrm{~d}$ immediately postcalving were not affected by precalving BCS but declined $(P<0.01)$ with increasing feeding level. The proportion of cows categorized as hypocalcemic (i.e., blood $\mathrm{Ca}<2.0 \mathrm{mmol} / \mathrm{L}$ ) during the critical 2-d period immediately postcalving was least in Feed75 (44, 12, and $4 \%$ of cows on $\mathrm{d} 0,1$, and 2 , relative to calving, respectively), greatest in Feed125 (65, 39, and 25\% of cows on d 0,1 , and 2, relative to calving, respectively), and intermediate in Feed100 (60, 35, and 15\% of cows on d 0,1 , and 2 , relative to calving, respectively). Cows in the BCS4 treatment group had lower blood Mg concentration $(P<0.01)$ during the first $4 \mathrm{~d}$ postcalving but not subsequently. Feeding level, however, did not affect blood $\mathrm{Mg}$ concentration.

\section{DISCUSSION}

The objective of the experiment was to create 2 different but homogeneous BCS groups and offer them 75, 100 , and $125 \%$ of their precalving energy requirements as fresh pasture by modifying their daily grazing allowance. Dry matter intakes as a percentage of BW were identical across the BCS categories $(1.2,1.6$, and $1.8 \%$ for Feed75, Feed100, and Feed125, respectively); therefore, ME intakes averaged approximately 75, 95, and $110 \%$ of estimated requirements, respectively. Thus, although the highest feed allocation did not achieve the targeted $125 \%$ of energy requirements, cows consumed $\mathrm{ME}$ in excess of requirements and their DMI probably reflects what is achievable in the weeks before calving in grazing cows. Measured changes in BW and BCS profiles precalving were also consistent with cows consuming ME in excess of requirements for maintenance, pregnancy, and activity.

To our knowledge, this is the first experiment, at least with grazing dairy cows, to investigate the relationship between precalving BCS and precalving level of feeding on production and reproduction variables, on indicators of EBAL, liver function and metabolic health, and on 
immunomodulatory compounds. The results indicate a complicated relationship between precalving BCS and precalving feeding level, with BCS affecting milk production, EBAL, the degree of hepatic lipidosis, and
PPAI, with precalving feeding level influencing early lactation EBAL, calcium homeostasis, and some indicators of metabolic health; however, as we hypothesized, the effects of feeding level on albumin:globulin ratio
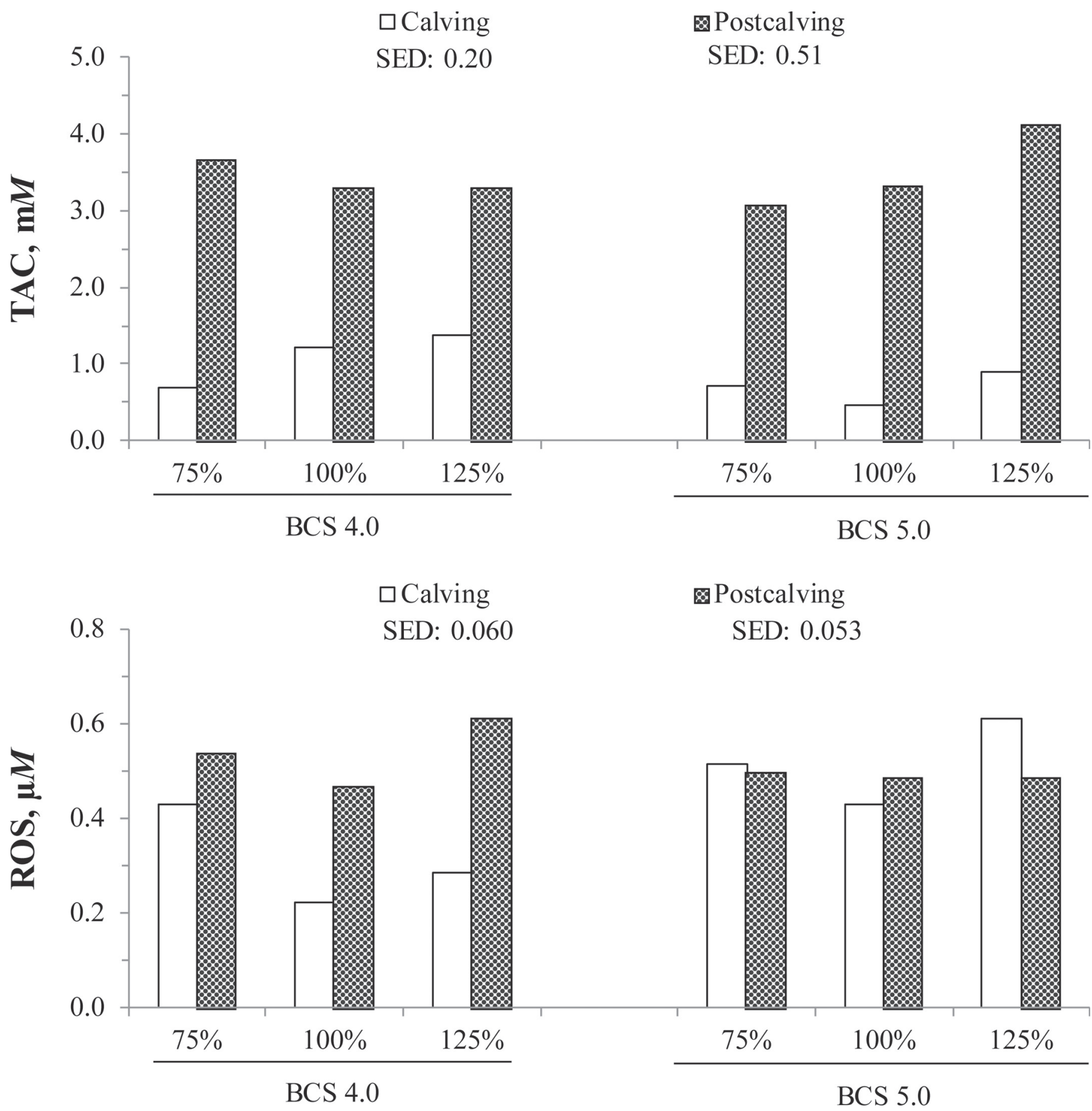

Figure 5. Effects of BCS 1 mo precalving and level of feeding before calving on plasma concentrations of total antioxidant capacity (TAC) and reactive oxygen species (ROS) at calving (i.e., mean of $\mathrm{d} 1$ and 4 postcalving) and postcalving (i.e., mean of $\mathrm{d} 7,14$ and 28 postcalving). Cows were either a BCS of 4 or 5 and offered 75,100 , and $125 \%$ of their energy requirements (Roche et al., 2005 ) for $23 \pm 5.6 \mathrm{~d}$ precalving. BCS was measured on a 1-10 scale, where 1 is emaciated and 10 is obese (Roche et al., 2004). SED $=$ SE of the difference. 

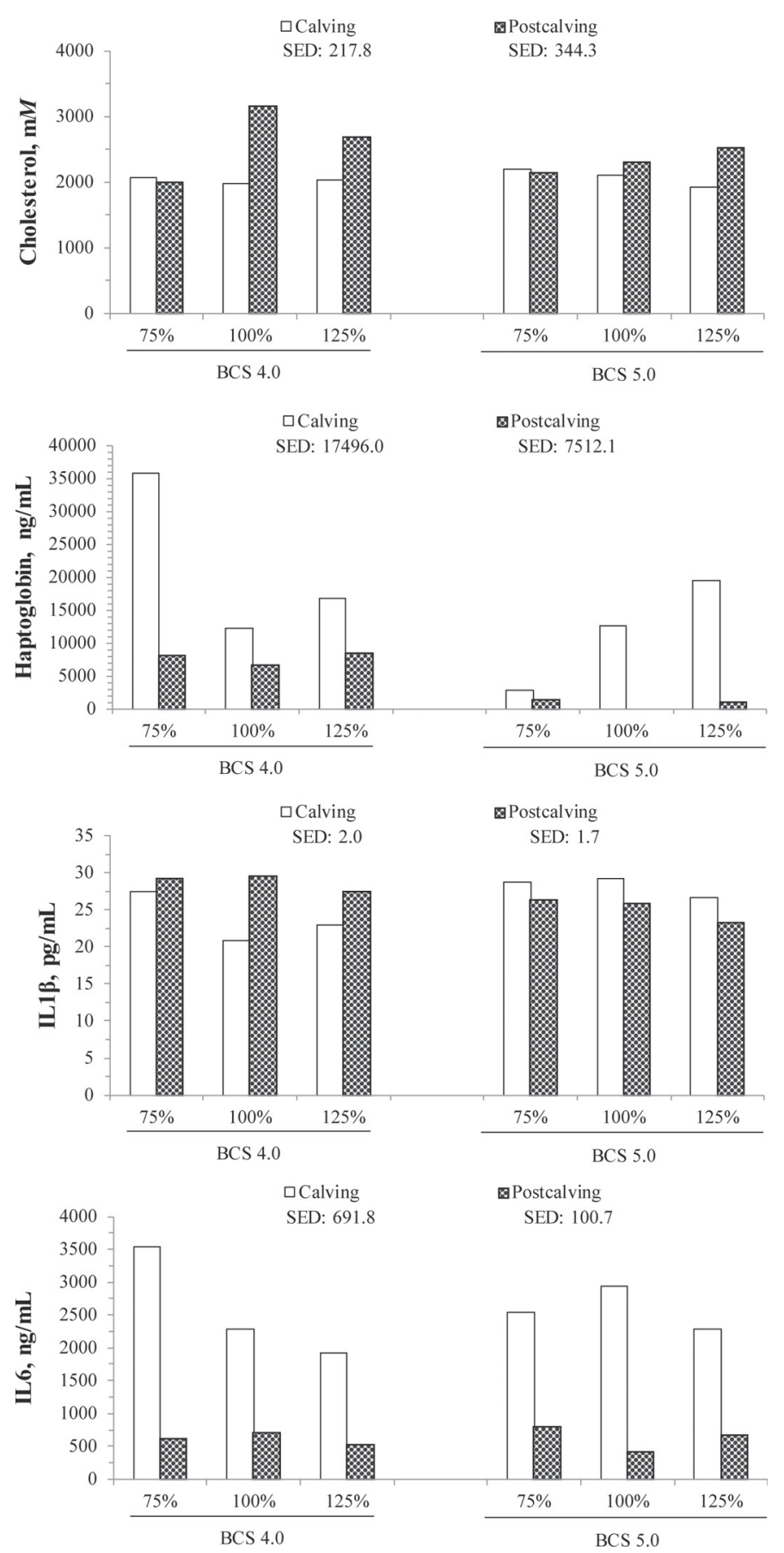

Figure 6. Effects of BCS 1 mo precalving and level of feeding before calving on plasma concentrations of indicators of immune competence/status at calving (i.e., mean of $\mathrm{d} 1$ and 4 postcalving) and postcalving (i.e., mean of d 7, 14 and 28 postcalving). Cows were either a BCS of 4 or 5 and offered 75,100 , and $125 \%$ of their energy requirements (Roche et al., 2005) for $23 \pm 5.6 \mathrm{~d}$ precalving. BCS was measured on a $1-10$ scale, where 1 is emaciated and 10 is obese (Roche et al., 2004). SED = SE of the difference. and circulating immunomodulatory compounds were dependent on the BCS state of the cow.

\section{Milk Production and EBAL}

Effect of Calving BCS. Cows in moderate condition at calving (i.e., BCS5) produced more milk but tended to be in a greater negative EBAL in early lactation compared with thinner cows (i.e., BCS4). This positive effect of calving BCS on milk production was predictable (Roche et al., 2009) and the size of the response was consistent with previous reports from grazing (Stockdale, 2001; Roche et al., 2009, 2013) and TMR (Waltner et al., 1993; Domecq et al., 1997) studies. Similarly, the greater BCS and BW loss and the greater circulating NEFA and BHBA in BCS5 cows are consistent with the reported decline in DMI with increasing BCS (Broster and Broster, 1998; Matthews et al., 2012) and the greater milk production. What is particularly novel about the current data set, however, is the degree of hepatic lipidosis evident in lower-yielding, moderately conditioned grazing dairy cows. To our knowledge, the extent of liver fat infiltration in early-lactation grazing cows has not been previously reported, but the results are consistent with those reported for TMR-fed cows (Bobe et al., 2004). In their review of the prevalence and severity of hepatic lipidosis, Bobe et al. (2004) defined 4 categories of hepatic lipidosis: (1) <1\%, (2) $1-5 \%$, (3) $5-10 \%$, and (4) $>10 \%$; within these categories, DMI was compromised in the most severe category, but health and reproduction were compromised in all but the lowest category. In the current study, 96 and $4 \%$ of BCS4 cows were in categories 2 and 3, respectively, whereas 49, 40, and $11 \%$ of BCS5 cows were in categories 2,3 , and 4 , respectively. Despite the high proportion of BCS5 cows in categories 3 and 4 compared with BCS4 cows, we found only limited evidence of a detrimental effect of the higher calving BCS on the indicators of health or immune function measured. For example, circulating concentrations of NEFA and BHBA were within normal ranges and blood albumin and albumin:globulin ratios were improved by the greater BCS (if anything, reflecting superior liver function), and milk production was greater than from cows in the BCS4 treatment group. However, the interaction between precalving BCS and feeding level in blood TAC and ROS immediately postcalving $(P<0.01)$ and during the first 4 wk postcalving $(P<0.05$ and $P=0.14$ for TAC and ROS, respectively) may reflect differences in the level of metabolic stress associated with precalving BCS. If cows in the BCS4-Feed75 treatment are ignored, blood TAC concentration is lower and ROS concentration is 
higher in the BCS5 cows during the period immediately postcalving. These results could indicate a negative effect of BCS5 and the associated high liver TAG on the level of metabolic stress occurring in early lactation. It also reflects increased metabolic stress in thin dairy cows underfed before calving. These results are yet further confirmation of the dangers of too high a BCS before calving (Roche et al., 2009).

Effect of Precalving Level of Feeding. Altering level of feeding precalving did not significantly affect milk production, but the extent of the negative EBAL postcalving increased with increasing level of feeding precalving; Feed75 cows calved 0.1 to 0.2 BCS units thinner than their better-fed counterparts but the difference declined with time. This is consistent with the linear increase $(P<0.05)$ in postcalving NEFA concentrations with increasing precalving feeding level, which reflects a greater net release of NEFA from adipose with increasing prepartum ME intake. This effect of precalving feeding level on postcalving EBAL is consistent across feeding systems (i.e., grazing or TMR) and cow milk yield (25-45 kg of milk/cow per day). Roche et al. (2005) and Roche (2007) reported the same effect in grazing dairy cows, with postcalving plasma NEFA and BW loss increasing with level of feeding precalving. Similarly, Agenäs et al. (2003) and Holtenius et al. (2003) reported less-severe negative EBAL and lower plasma NEFA concentrations, respectively, in TMR-fed cows subjected to a feed restriction for more than $8 \mathrm{wk}$ prepartum. Douglas et al. (2006), Janovick and Drack-

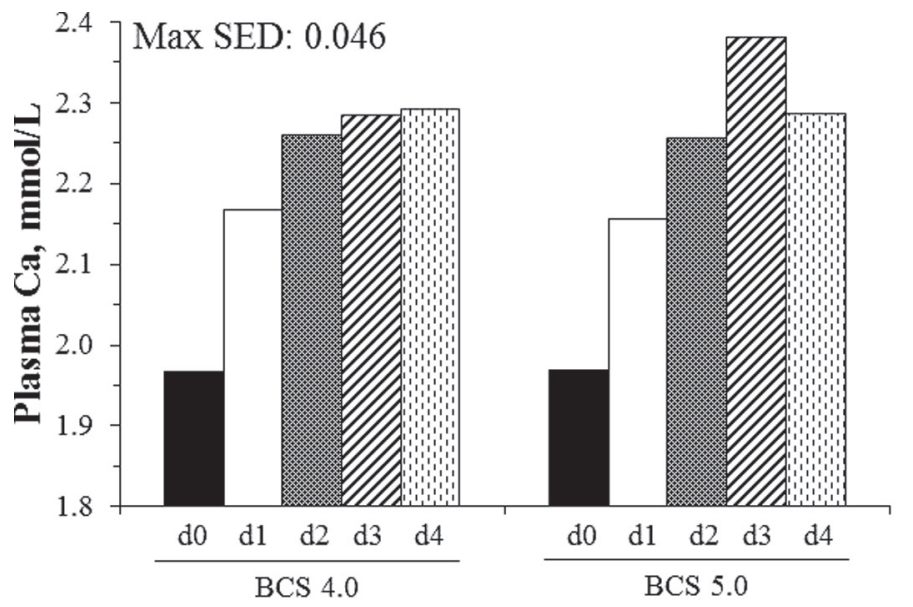

Body condition score

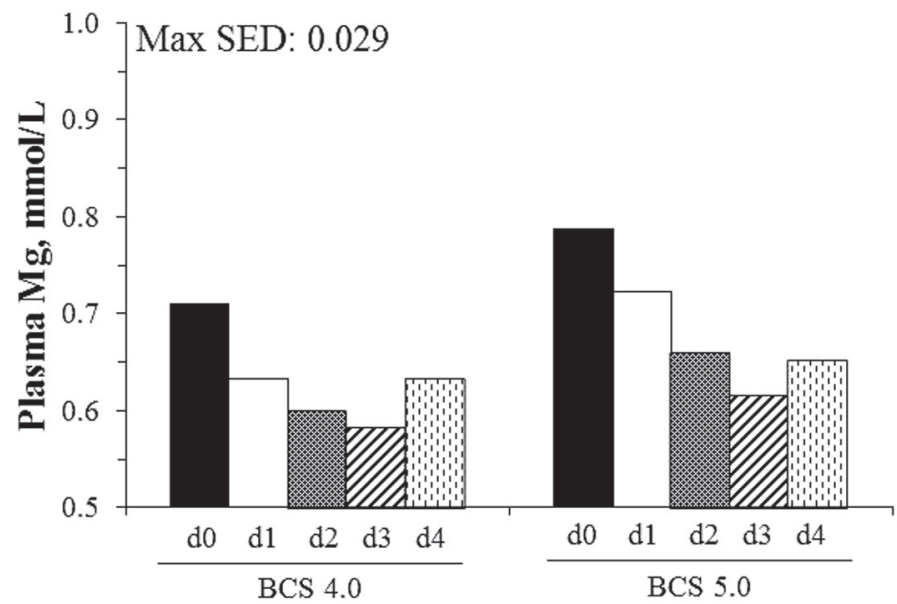

Body condition score

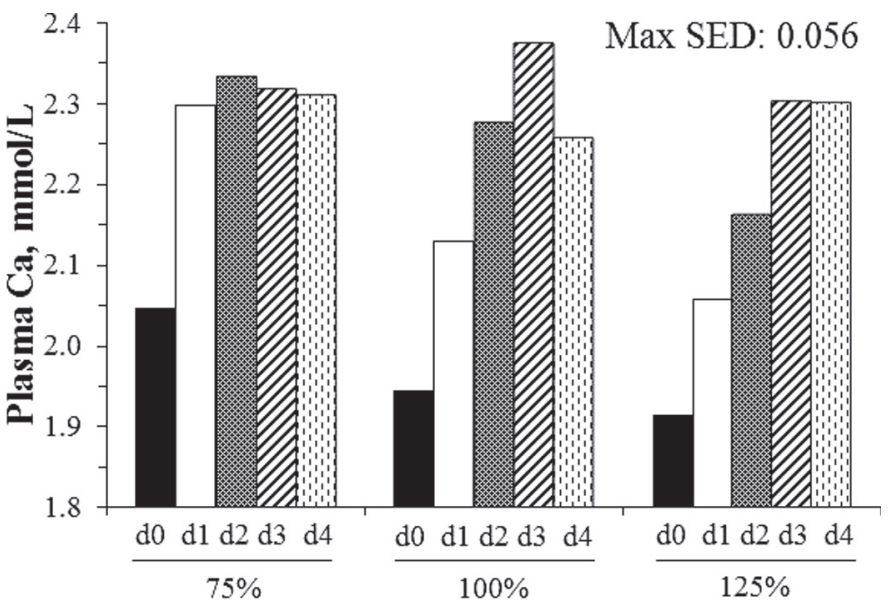

Level of feeding

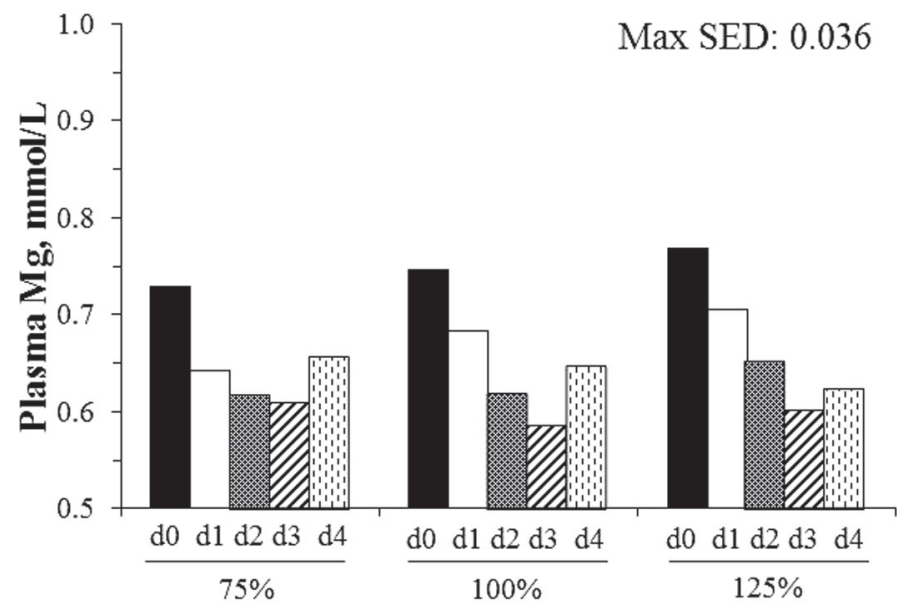

Level of feeding

Figure 7. Effects of BCS 1 mo precalving and level of feeding before calving on plasma Ca and Mg concentrations on the day of calving and the first $4 \mathrm{~d}$ postcalving. Cows were either a BCS of 4 or 5 and offered 75 , 100, and 125\% of their energy requirements (Roche et al., 2005) for $23 \pm 5.6 \mathrm{~d}$ precalving. BCS was measured on a 1-10 scale, where 1 is emaciated and 10 is obese (Roche et al., 2004). There was no interaction; therefore, main effects are presented. SED = SE of the difference. 
ley (2010), and Janovick et al. (2011) also reported greater DMI, less BW loss, and lower plasma NEFA postpartum in TMR-fed cows subjected to a feed restriction precalving compared with cows that were fed in excess of their energy requirements. Collectively, these data highlight a consistent effect of precalving energy intake on postcalving EBAL that is not affected by calving BCS, feeding system, or milk production of the cow.

The lack of effect of precalving feeding level on milk production is also consistent with previous studies. Although mass balance of energy would support this, with the reduced release of NEFA counteracted by greater DMI in early lactation (Roche et al., 2005; Douglas et al., 2006), it is also possible that this lack of effect on milk production reflects insufficient statistical power in the experiments undertaken. Agenäs et al. (2003) and Douglas et al. (2006) both reported small numerical increases in milk yield in cows restricted before calving, but the differences were not significant. Similarly, in the study reported here, milk yield was not affected by precalving feeding level, but there was an interaction at wk $12(P=0.06)$, wherein the BCS5-Feed125 cows produced 1.1 and $1.3 \mathrm{~kg}$ less milk/d than the BCS5Feed75 and BCS5-Feed100 cows, respectively, whereas the BCS4-Feed125 cows produced 0.5 and $0.4 \mathrm{~kg}$ milk/d more than the BCS4-Feed75 and BCS4-Feed100 cows, respectively. This numerical difference in milk production appears to have increased from wk 6 postcalving and continued beyond the period of experimental measurements. For example, on average, during wk 13 to 18 (data not presented), BCS5-Feed75 and BCS5-Feed 100 cows produced 1.0 and $1.2 \mathrm{~kg} / \mathrm{d}$ more milk, respectively, than BCS5-Feed 125 cows $(P=0.2)$. In future studies, greater cow numbers and longer studies will be required to determine if precalving level of feeding affects milk production.

Unlike previous studies (Douglas et al., 2006; Loor et al., 2006; Janovick et al., 2011) and despite the significant effect on plasma NEFA, precalving feeding level did not affect mean liver TAG content nor the proportion of cows in the 4 hepatic lipidosis categories (Bobe et al., 2004). The reason for this is unclear, but may reflect study differences in precalving level of feeding, the length of excessive intake precalving, or precalving BCS. Whatever the reason, this is reflected in the treatment differences in plasma NEFA concentration. In the current study, NEFA concentration during the first week postpartum was $0.19 \mathrm{mmol} / \mathrm{L}$ lower in Feed75 than in Feed125 cows. In comparison, during the same period, Holtenius et al. (2003) and Douglas et al. (2006) reported that NEFA concentrations were $0.2-0.3$ and $0.5 \mathrm{mmol} / \mathrm{L}$ lower, respectively, in feed-restricted treatment cows compared with those fed to excess. In addi- tion, cow BCS was greater in these earlier studies than in the experiment presented here; cows in the experiment reported by Agenäs et al. (2003) and Douglas et al. (2006) were 0.25 to 0.5 BCS units fatter at calving (5-point scale) than the BCS5 cows in the current experiment (converted using equations reported in Roche et al., 2004). This difference in BCS may be sufficient to create an environment that would benefit to a greater extent from a precalving feed restriction. For example, Gillund et al. (2001) reported a doubling of the risk of ketosis at BCS 6.0 compared with BCS 5.5, and Roche et al. (2013) reported that $40 \%$ of cows calving at BCS 5.5 could be classified as ketotic, whereas no cows calving at BCS 4.5 were ketotic. In the current study, $<10 \%$ of BCS5 cows would be classified as ketotic using the same criteria as in Roche et al. (2013). Collectively, these results are consistent with an optimum BCS of 5.0 (3.0 in a 5-point scale; Roche et al., 2009), with the increased milk production from higher BCS finely balanced with excessive BCS loss and the increased risk of hepatic lipidosis, ketosis, and associated metabolic disorders (e.g., displaced abomasa).

In summary, it is plausible that the BCS5 cows in the present study were not sufficiently fat as to benefit from a positive effect of a restricted precalving feeding level on postcalving liver TAG. Future research investigating the interaction between precalving BCS and level of feeding should examine the effect of level of feeding in over-conditioned cows (BCS $\geq 5.5$ ) relative to optimally conditioned cows (BCS 5.0) to better define the criteria under which a precalving feed restriction will improve the odds of a successful transition across calving.

\section{Eucalcemia}

The negative effect of precalving feeding level on postcalving plasma calcium concentrations in the $3 \mathrm{~d}$ after calving is noteworthy. Roche and Berry (2006) reported that $88 \%$ of milk fever incidences occurred within $24 \mathrm{~h}$ of calving, and Roche et al. (2002) noted a lack of effect of calcium supplementation on blood calcium concentration after 2 DIM, indicating a stabilization of the calcium homeostatic mechanisms by this time. Therefore, to examine the effect of any transition cow management strategy on calcium homeostasis, it is necessary to consider the effect on blood calcium on the day of calving and the $2 \mathrm{~d}$ immediately following calving. Although BCS has been historically implicated as a risk factor in milk fever (Roche et al., 2009), it is generally extremes in BCS (i.e., too thin or too fat) that increase the risk of occurrence (Roche and Berry, 2006). The lack of effect of the BCS categories investigated in this study supports that premise. However, the increase in blood calcium concentrations and the reduc- 
tion in the proportion of cows classified as hypocalcemic (blood $\mathrm{Ca}<2.0 \mathrm{mmol} / \mathrm{L}$ ) in Feed75 in the current study, irrespective of precalving BCS, offers a potential strategy for milk fever prevention. Although reducing DCAD to $<0 \mathrm{mEq} / \mathrm{kg}$ of DM has been reported to have the same biochemical and eucalcemic effects in pasturefed cows as those reported in TMR-fed cows (Goff and Horst, 1997; Roche et al., 2003), logistical difficulties in achieving a negative DCAD (e.g., a lack of control of diet mineral content and daily DMI, a high base DCAD, and a requirement for large amounts of anionic salts) make the strategy impractical under grazing systems. There is, therefore, a need for a practical solution to milk fever in grazing dairy cows. Both Roche et al. (2005) and Roche (2007) reported an increase in blood calcium on the day of calving and the days immediately following calving in cows that were feed restricted before calving. In fact, the data presented by Roche et al. (2005) indicate a negative linear effect of precalving feeding level on blood calcium on the day of calving, the period when most milk fever presents (Roche and Berry, 2006). Experiments undertaken at the University of Illinois confirm this effect of precalving feeding level on peripartum blood calcium concentration (J. K. Drackley, University of Illinois, Urbana; personal communication). The measurements taken do not allow us to speculate on the physiological mechanisms underpinning the difference in blood calcium; further research is required to understand the role of precalving DMI in calcium homeostasis.

\section{Liver Function and Immunomodulatory Factors}

Both precalving BCS and precalving feeding level affected indicators of liver function, metabolic stress, peripartum inflammation, and immune function, but the relationship is complicated. We used concentrations of total blood protein, albumin, and cholesterol as indicators of liver function (Bertoni and Trevisi, 2013), TAC and ROS as indicators of metabolic stress, and circulating concentrations of negative (albumin) and positive $(\mathrm{Hp})$ acute phase proteins, and pro-inflammatory cytokines (IL-1 $\beta$ and IL-6) as indicators of inflammatory state.

Blood Proteins and Positive and Negative Acute Phase Proteins. Collectively, the blood protein data indicate an interaction between precalving BCS and feeding level, such that the level of inflammation postcalving was greater in BCS4-Feed75 cows than in BCS4-Feed100 or BCS4-Feed125 cows, but the opposite effect of precalving feeding level on inflammatory state was evident in BCS5 cows. Both blood albumin and the albumin:globulin ratio were greater in BCS5 cows. This is consistent with a recent report on the effect of BCS on indicators of health and welfare in grazing cows (Roche et al., 2013), wherein precalving blood albumin concentration declined at both low and high BCS. The effect of BCS on blood albumin and the albumin:globulin ratio continues postcalving, but it is complicated by an interaction with precalving feeding level; blood albumin concentration declined with precalving feeding level on the day of calving and d 1 postcalving and this effect was mirrored in blood albumin:globulin ratio. However, this effect was a result of a large effect of precalving feeding level on blood albumin in BCS5 cows $(1-1.8 \mathrm{~g} / \mathrm{L})$, with no effect in BCS4 cows. The interaction between precalving BCS and precalving level of feeding continued through early lactation. There was no effect of either precalving BCS or precalving feeding level on blood cholesterol concentration, an indicator of hepatic lipoprotein production (Bertoni and Trevisi, 2013). However, numerical differences indicate greater plasma cholesterol concentrations postcalving in BCS4 cows in the Feed100 and Feed125 treatments than in the Feed75 treatment cows. No such effect was evident in BCS5 cows. Haptoglobin concentrations were not significantly affected by imposed treatments, although in the $4 \mathrm{~d}$ following calving it appears that concentrations declined $(P=0.17)$ in BCS4 cows and increased in BCS5 cows with increasing precalving DMI.

Blood albumin and the apolipoproteins (i.e., as indicated by blood cholesterol) are negative acute phase proteins considered important in the liver activity index described by Trevisi et al. (2001); they decline during periods of inflammation as the liver increases its production of positive acute phase proteins, such as $\mathrm{Hp}$ (Bertoni et al., 2008; Bertoni and Trevisi, 2013). Low blood albumin has been implicated in subclinical endometritis (Burke et al., 2010) and cows categorized as having a low liver activity index (i.e., low albumin and cholesterol) produced less milk and were less likely to become pregnant (Bertoni et al., 2008). Furthermore, cows with higher blood albumin and cholesterol had lower concentrations of $\mathrm{Hp}$ and bilirubin and greater concentrations of urea, confirming their role as indicators of liver function. These published relationships make the current data set all the more intriguing; interactions between precalving BCS and precalving feeding level and nonsignificant numerical differences in these positive and negative acute phase proteins indicate that the benefit of a controlled restriction of energy intake precalving will only be evident in cows $\geq$ BCS 5 (i.e., BCS 3 in a 5-point scale) and that thinner cows will probably be disadvantaged through a precalving feed restriction.

Metabolic Stress and Inflammatory State. The presented BCS $\times$ level of feeding interactions in blood 
TAC and ROS concentration and pro-inflammatory cytokines are consistent with the liver function results discussed earlier; however, the effect was largely limited to the $4 \mathrm{~d}$ following calving. Mammals have evolved complex antioxidant strategies to utilize oxygen and minimize the noxious effects of its partially reduced species. Antioxidants within cells, cell membranes, and extracellular fluids can be upregulated and mobilized to neutralize excessive and inappropriate ROS formation (Ghiselli et al., 2000). Total antioxidant capacity considers the cumulative action of all the antioxidants present in plasma and body fluids, thus providing an integrated antioxidant parameter (Ghiselli et al., 2000), whereas circulating concentrations of ROS is a measure of oxidative stress. Therefore, greater TAC and lower ROS would indicate a more desirable metabolic state.

The greater ROS and lower TAC in BCS4 cows in the Feed75 treatment compared with the other BCS4 cows indicates a greater degree of metabolic stress in these cows; this is also consistent with the greater circulating concentrations of the pro-inflammatory cytokines IL-1 $\beta$ and IL-6 in this treatment group during the $4 \mathrm{~d}$ immediately postcalving. Interestingly, BCS5-Feed125 also had greater circulating concentrations of ROS and lower TAC compared with the other BCS5 treatment groups. The higher concentrations of Hp in both BCS4Feed75 and BCS5-Feed125 are also noteworthy. Collectively, the metabolic indices signify a greater degree of metabolic stress and inflammation in restricted BCS4 cows and in overfed BCS5 cows. The transitory nature of the effect of feeding level treatment in BCS4 cows is also noteworthy. In our opinion, this should not be taken as evidence that the cow adapts successfully to the BCS and feeding state she has been subjected to precalving. There is clear evidence that immune competence is reduced peripartum (Sordillo and Raphael, 2013) and it would appear that this is a normal state in all cows (Heiser et al., 2015). However, it is also clear that this reduction in immune competence should not extend beyond the first week of lactation (Heiser et al., 2015). The data presented here indicate an effect of long- (BCS) and short-term nutrition on the severity of this reduction in immune competence, and the timing of this effect is consistent with the changes in immune-system responsiveness to a modeled cytokine storm (Heiser et al., 2015). An accentuated or extended reduction in immune competence may be a key indicator of cows failing to transition optimally through calving. The trend for a greater reduction in immune competence in thin, underfed cows before calving likely reflects a greater susceptibility to disease and an increased likelihood of a failed transition. Although we cannot rule out that the physical restriction of feed contributed to the negative metabolic profile presented, it is unlikely because the volume of fresh forage that would have to be consumed to achieve the restricted DMI was still considerable and the feed was benign, in terms of the likelihood of a rumen upset. The results more likely highlight a complex interaction between BCS state precalving, feeding level precalving, and the timing of measurement of immunomodulatory compounds in the days and weeks postcalving.

\section{CONCLUSIONS}

Precalving BCS and precalving feeding level have both independent and interdependent effects on production and health characteristics of transition dairy cows. Irrespective of precalving BCS, a controlled restriction precalving reduced NEFA release postpartum and increased plasma calcium concentrations, reducing the risk of milk fever. Fatter cows produced more milk but had a greater BCS loss postpartum and both a greater level of liver fat infiltration and a greater risk of metabolic diseases associated with excessive hepatic lipidosis. In comparison, thinner cows are at risk of an accentuated reduction in peripartum immune competence if subjected to a feed restriction before calving, probably increasing the risk of infectious diseases. It would appear from this data set that optimally conditioned cows will benefit from a short-term (2-3 wk) controlled feed restriction (75-90\% of requirements), whereas cows in less-than-optimal condition should be fed to requirements before calving. Future work should focus on the relationship between BCS and precalving feeding level in moderate- to over-conditioned dairy cows.

\section{ACKNOWLEDGMENTS}

The authors thank Jason Philips (farm manager, Scott Farm, DairyNZ) and his capable team, as well as Stu Morgan, Kate Watkins, Hamish Hodgson, and Chris Roach for technical support, and Barbara Dow and Barbara Kuhn-Sherlock (DairyNZ) for statistical analysis and advice. This research was supported by New Zealand dairy farmers through DairyNZ Inc. (RD1403) and the Ministry of Business, Innovation, and Employment (DRCX1201).

\section{REFERENCES}

Agenäs, S., E. Burstedt, and K. Holtenius. 2003. Effects of feeding intensity during the dry period. 1. Feed intake and milk production. J. Dairy Sci. 86:870-882.

Akbar, H., M. Bionaz, D. B. Carlson, S. L. Rodriguez-Zas, R. E. Everts, H. A. Lewin, J. K. Drackley, and J. J. Loor. 2013. Feed restriction, but not L-carnitine infusion, alters the liver transcriptome by inhibiting sterol synthesis and mitochondrial oxidative 
phosphorylation and increasing gluconeogenesis in mid-lactation dairy cows. J. Dairy Sci. 96:2201-2213.

Akbar, H., T. M. Grala, M. Vailati Riboni, F. C. Cardoso, G. Verkerk, J. McGowan, K. Macdonald, J. Webster, K. Schutz, S. Meier, L. Matthews, J. R. Roche, and J. J. Loor. 2015. Body condition score at calving affects systemic and hepatic transcriptome indicators of inflammation and nutrient metabolism in grazing dairy cows. J. Dairy Sci. 98:1019-1031. http://dx.doi.org/10.3168/jds.2014-8584.

Bell, A. W. 1995. Regulation of organic nutrient metabolism during transition from late pregnancy to early lactation. J. Anim. Sci. 73:2804-2819.

Bertics, S. J., R. R. Grummer, C. Cadorniga-Valino, and E. E. Stoddard. 1992. Effect of prepartum dry matter intake on liver triglyceride concentration and early lactation. J. Dairy Sci. 75:1914-1922.

Bertoni, G., and E. Trevisi. 2013. Use of the liver activity index and other metabolic variables in the assessment of metabolic health in dairy herds. Vet. Clin. North Am. Food Anim. Pract. 29:413-431.

Bertoni, G., E. Trevisi, X. Han, and M. Bionaz. 2008. Effects of inflammatory conditions on liver activity in puerperium period and consequences for performance in dairy cows. J. Dairy Sci. 91:3300-3310.

Bobe, G., J. W. Young, and D. C. Beitz. 2004. Invited review: Pathology, etiology, prevention, and treatment of fatty liver in dairy cows. J. Dairy Sci. 87:3105-3124.

Boutflour, R. B. 1928. Limiting factors in the feeding and management of milk cows. Pages 15-20 in Rep World's Dairy Congress, Central Hall, Westminster, London, UK.

Broster, W. H., and V. J. Broster. 1998. Body score of dairy cows. J. Dairy Res. 65:155-173.

Burke, C. R., S. Meier, S. McDougall, C. Compton, M. Mitchell, and J. R. Roche. 2010. Relationships between endometritis and metabolic state during the transition period in pasture-grazed dairy cows. J. Dairy Sci. 93:5363-5373.

Burton, J. L., S. A. Madsen, J. Yao, S. S. Sipkovsky, and P. M. Coussens. 2001. An immunogenomics approach to understanding periparturient immunosuppression and mastitis susceptibility in dairy cows. Acta Vet. Scand. 42:407-424.

Crookenden, M. A., V. S. R. Dukkipati, A. Heiser, J. Kay, J. J. Loor, J. McGowan, M. D. Mitchell, S. Morgan, K. M. Moyes, A. Murray, C. G. Walker, and J. R. Roche. 2014. Parturition in dairy cows temporarily alters the expression of genes involved in neutrophil attachment. Pages 413-416 in Proc. 5th Australasian Dairy Science Symposium. http://www.adssymposium.com.au/ listProductByBrand/Mallory+Crookenden/6.+Nutrition+and $+\mathrm{A}$ nimal + Health $/ 6 .+$ Nutrition + and + Animal + Health .

Domecq, J. J., A. L. Skidmore, J. W. Lloyd, and J. B. Kaneene. 1997. Relationship between body condition scores and milk yield in a large dairy herd of high yielding Holstein cows. J. Dairy Sci. 80:101-112.

Douglas, G. N., T. R. Overton, H. G. Bateman 2nd, H. M. Dann, and J. K. Drackley. 2006. Prepartal plane of nutrition, regardless of dietary energy source, affects periparturient metabolism and dry matter intake in Holstein cows. J. Dairy Sci. 89:2141-2157.

Drackley, J. K. 1999. ADSA Foundation Scholar Award. Biology of dairy cows during the transition period: The final frontier? J. Dairy Sci. 82:2259-2273.

Dyk, P. B., R. S. Emery, J. L. Liesman, H. F. Bucholtz, and M. J. VandeHaar. 1995. Prepartum non-esterified fatty acids in plasma are higher in cows developing periparturient health problems. J. Dairy Sci. 78:337.

Ghiselli, A., M. Serafini, F. Natella, and C. Scaccini. 2000. Total antioxidant capacity as a tool to assess redox status: Critical view and experimental data. Free Radic. Biol. Med. 29:1106-1114.

Gillund, P., O. Reksen, Y. T. Grohn, and K. Karlberg. 2001. Body condition related to ketosis and reproductive performance in Norwegian dairy cows. J. Dairy Sci. 84:1390-1396.

Goff, J. P., and R. L. Horst. 1997. Physiological changes at parturition and their relationship to metabolic disorders. J. Dairy Sci. 80:1260-1268.
Goldhawk, C., N. Chapinal, D. M. Veira, D. M. Weary, and M. A. G. von Keyserlingk. 2009. Prepartum feeding behavior is an early indicator of subclinical ketosis. J. Dairy Sci. 92:4971-4977.

Graugnard, D. E., K. M. Moyes, E. Trevisi, M. J. Khan, D. Keisler, J. K. Drackley, G. Bertoni, and J. J. Loor. 2013. Liver lipid content and inflammometabolic indices in peripartal dairy cows are altered in response to prepartal energy intake and postpartal intramammary inflammatory challenge. J. Dairy Sci. 96:918-935.

Heiser, A., A. McCarthy, N. Wedlock, S. Meier, J. Kay, C. Walker, M. A. Crookenden, M. D. Mitchell, S. Morgan, K. Watkins, J. J. Loor, and J. R. Roche. 2015. Grazing dairy cows had decreased interferon- $\gamma$, tumor necrosis factor, and interleukin-17, and increased expression of interleukin-10 during the first week after calving. J. Dairy Sci. 98:937-946. http://dx.doi.org/10.3168/ jds.2014-8494.

Holtenius, K., S. Agenäs, C. Delavaud, and Y. Chilliard. 2003. Effects of feeding intensity during the dry period. 2. Metabolic and hormonal responses. J. Dairy Sci. 86:883-891.

Huzzey, J. M., D. M. Veira, D. M. Weary, and M. A. G. von Keyserlingk. 2007. Prepartum behavior and dry matter intake identify dairy cows at risk for metritis. J. Dairy Sci. 90:3220-3233.

VSN International. 2011. GenStat for Windows 14th ed. VSN International, Hemel Hempstead, UK.

Janovick, N. A., Y. R. Boisclair, and J. K. Drackley. 2011. Prepartum dietary energy intake affects metabolism and health during the periparturient period in primiparous and multiparous Holstein cows. J. Dairy Sci. 94:1385-1400.

Janovick, N. A., and J. K. Drackley. 2010. Prepartum dietary management of energy intake affects postpartum intake and lactation performance by primiparous and multiparous Holstein cows. J. Dairy Sci. 93:3086-3102.

Ji, P., J. K. Drackley, M. J. Khan, and J. J. Loor. 2014. Overfeeding energy upregulates peroxisome proliferator-activated receptor (PPAR) $\gamma$-controlled adipogenic and lipolytic gene networks but does not affect proinflammatory markers in visceral and subcutaneous adipose depots of Holstein cows. J. Dairy Sci. 97:3431-3440.

LeBlanc, S. 2010. Monitoring metabolic health of dairy cattle in the transition period. J. Reprod. Dev. 56(Suppl.):S29-35.

Loor, J. J., H. M. Dann, N. A. Janovick Guretzky, R. E. Everts, R. Oliveira, C. A. Green, N. B. Litherland, S. L. Rodriguez-Zas, H. A. Lewin, and J. K. Drackley. 2006. Plane of nutrition prepartum alters hepatic gene expression and function in dairy cows as assessed by longitudinal transcript and metabolic profiling. Physiol. Genomics 27:29-41.

Macdonald, K., and J. R. Roche. 2004. Condition Scoring Made Easy. DairyNZ, Hamilton, New Zealand.

Mandok, K. S., J. K. Kay, S. L. Greenwood, G. R. Edwards, and J. R. Roche. 2013. Requirements for zero energy balance of nonlactating, pregnant dairy cows fed fresh autumn pasture are greater than currently estimated. J. Dairy Sci. 96:4070-4076.

Matthews, L. R., C. Cameron, A. J. Sheahan, E. S. Kolver, and J. R. Roche. 2012. Associations among dairy cow body condition and welfare-associated behavioral traits. J. Dairy Sci. 95:2595-2601.

McDougall, S., R. Macaulay, and C. Compton. 2007. Association between endometritis diagnosis using a novel intravaginal device and reproductive performance in dairy cattle. Anim. Reprod. Sci. 99:9-23.

Priest, N. V., S. McDougall, C. R. Burke, J. R. Roche, M. Mitchell, K. L. McLeod, S. L. Greenwood, and S. Meier. 2013. The responsiveness of subclinical endometritis to a nonsteroidal antiinflammatory drug in pasture-grazed dairy cows. J. Dairy Sci. 96:4323-4332.

Roche, J. R. 2007. Milk production responses to pre- and postcalving dry matter intake in grazing dairy cows. Livest. Sci. 110:12-24.

Roche, J. R. 2012. Avoiding metabolic diseases around calving. DairyNZ Technical Series 10:13-18. Accessed Dec. 12, 2014. http://www.dairynz.co.nz/publications/technical-series/technicalseries-june-2012/.

Roche, J. R., and D. P. Berry. 2006. Periparturient climatic, animal, and management factors influencing the incidence of milk fever in grazing systems. J. Dairy Sci. 89:2775-2783. 
Roche, J. R., P. G. Dillon, C. R. Stockdale, L. H. Baumgard, and M. J. VanBaale. 2004. Relationships among international body scoring systems. J. Dairy Sci. 87:3076-3079.

Roche, J. R., N. C. Friggens, J. K. Kay, M. W. Fisher, K. J. Stafford, and D. P. Berry. 2009. Invited review: Body condition score and its association with dairy cow productivity, health, and welfare. J. Dairy Sci. 92:5769-5801.

Roche, J. R., E. S. Kolver, and J. K. Kay. 2005. Influence of precalving feed allowance on periparturient metabolic and hormonal responses and milk production in grazing dairy cows. J. Dairy Sci. 88:677-689.

Roche, J. R., K. A. Macdonald, K. E. Schutz, L. R. Matthews, G. A. Verkerk, S. Meier, J. J. Loor, A. R. Rogers, J. McGowan, S. R. Morgan, S. Taukiri, and J. R. Webster. 2013. Calving body condition score affects indicators of health in grazing dairy cows. J. Dairy Sci. 96:5811-5825.

Roche, J. R., J. Morton, and E. Kolver. 2002. Sulfur and chlorine play a non-acid base role in periparturient calcium homeostasis. J. Dairy Sci. 85:3444-3453.

Schmitt, E., M. A. Ballou, M. N. Correa, E. J. DePeters, J. K. Drackley, and J. J. Loor. 2011. Dietary lipid during the transition period to manipulate subcutaneous adipose tissue peroxisome proliferator-activated receptor- $\gamma$ co-regulator and target gene expression. J. Dairy Sci. 94:5913-5925.
Sheehy, M. R., F. J. Mulligan, and A. G. Fahey. 2014. A comparison of serum metabolic profiles of dairy cows that maintained or lost body condition score 15 d before calving. J. Dairy Sci. 97(E-Suppl. 1):283. (Abstr.)

Sordillo, L. M., and W. Raphael. 2013. Significance of metabolic stress, lipid mobilization, and inflammation on transition cow disorders. Vet. Clin. North Am. Food Anim. Pract. 29:267-278.

Stockdale, C. R. 2001. Body condition at calving and the performance of dairy cows in early lactation under Australian conditions: A review. Aust. J. Exp. Agric. 41:823-829.

Trevisi, E., L. Calamari, and G. Bertoni. 2001. Definition of liver activity index in the dairy cow and its relationship with the reproductive performance. Pages 118-119 in Proc. X Int. Symp. Vet. Lab. Diagn., Salsomaggiore-Parma, Italy. Societa Italiana di Diagnostica e di Laboratorio Veterinaria, Salsomaggiore, Italy.

Verbyla, A. P., B. R. Cullis, M. G. Kenward, and S. J. Welham. 1999 The analysis of designed experiments and longitudinal data by using smoothing splines (with discussion). Appl. Stat. 48:269-311.

Waltner, S. S., J. P. McNamara, and J. K. Hillers. 1993. Relationships of body condition score to production variables in high producing Holstein dairy cows. J. Dairy Sci. 76:3410-3419. 